Published in final edited form as:

Prog Neuropsychopharmacol Biol Psychiatry. 2013 January 10; 40: 70-82. doi:10.1016/j.pnpbp. 2012.08.011.

\title{
Ghrelin and Eating Disorders
}

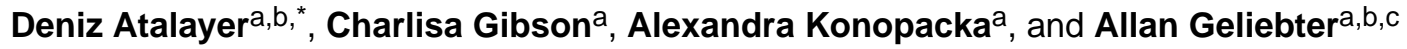 \\ Charlisa Gibson: charlisa.gibson@gmail.com; Alexandra Konopacka: alexandra.aek@gmail.com; Allan Geliebter: \\ ag58@columbia.edu \\ aDepartment of Medicine, New York Obesity Research and Nutrition Center, St. Luke's-Roosevelt \\ Hospital, New York NY, USA \\ bepartment of Psychiatry, Columbia University College of Physicians and Surgeons, New York, \\ NY, USA \\ 'Department of Psychology, Touro College, New York, NY, USA
}

\section{Abstract}

There is growing evidence supporting a multifactorial etiology that includes genetic, neurochemical, and physiological components for eating disorders above and beyond the more conventional theories based on psychological and sociocultural factors. Ghrelin is one of the key gut signals associated with appetite, and the only known circulating hormone that triggers a positive energy balance by stimulating food intake. This review summarizes recent findings and several conflicting reports on ghrelin in eating disorders. Understanding these findings and inconsistencies may help in developing new methods to prevent and treat patients with these disorders.

\section{Keywords}

Ghrelin; Anorexia Nervosa; Bulimia Nervosa; Binge Eating Disorder; Des-acyl Ghrelin

\section{Introduction}

There is now some reassuring evidence that the prevalence for anorexia nervosa (AN) has remained stable and that the prevalence has actually decreased for bulimia nervosa over the past decades (Smink et al., 2012). However, the associated mortality rate of eating disorders (EDs) particularly AN, as well as the comorbidities with other psychiatric disorders (e.g., OCD ) (Altman and Shankman, 2009) and mood states (e.g., depression, anxiety) (McElroy et al., 2010) have encouraged researchers to investigate the underlying pathology of EDs. Contrary to the popular view that EDs are due solely due to psychological and sociocultural factors, new research has implicated genetic, neurochemical, and physiological substrates (Frank et al., 2005; Helder and Collier, 2011; Kaye et al., 2011; Scherag et al., 2010). Changes in hormones involved in energy balance and food intake via the neurohumoral axis may also be associated with or contribute to EDs (Prince et al., 2009; Tong and D'Alessio, 2011).

Corresponding author: Deniz Atalayer, PhD, NY Nutrition Obesity Research Center, St. Luke's-Roosevelt Hospital, Columbia University Medical Center, 440 W $114^{\text {th }}$ St. Room 8-915, New York, NY 10025, Tel: 212-5232371 (work), Fax: 212-6361829, da2458@columbia.edu.

Publisher's Disclaimer: This is a PDF file of an unedited manuscript that has been accepted for publication. As a service to our customers we are providing this early version of the manuscript. The manuscript will undergo copyediting, typesetting, and review of the resulting proof before it is published in its final citable form. Please note that during the production process errors may be discovered which could affect the content, and all legal disclaimers that apply to the journal pertain. 
One of the key hormones involved with appetite and food intake is ghrelin. Although there are several neuropeptides stimulating food intake, ghrelin is the only established orexigenic gut peptide to date. Its circulating levels increase during fasting and decrease following a meal (Erlanson-Albertsson, 2005). In 1996, Howard et al. cloned a G protein-coupled seventransmembrane receptor of the rat and human pituitary gland and hypothalamus that can trigger growth hormone (GH) release (Howard et al., 1996) when bound to a ligand. The endogenous ligand for this receptor, however, was not known until 1999 (Kojima et al., 1999); when ghrelin, a 28-amino-acid peptide hormone, was confirmed to bind to the growth hormone secretagogue receptor-1A (GHS-R1A). At present, ghrelin's role in EDs has not been well elucidated, but new data suggest a link. Differences in basal fasting levels and/or meal-stimulated (postprandial) ghrelin levels have been reported in individuals with EDs (vs. normal). To improve our understanding of the neurohumoral aspects of ED's, we will review the relevant research on ghrelin associated with EDs.

\section{Ghrelin Gene-Derived Products}

Ghrelin is first cleaved from the 94 amino-acid preproghrelin polypeptide at the $\mathrm{N}$-terminal by the prohormone convertase 1/3 (PC 1/3). A hydroxyl group of the third-N terminal amino-acid serine (Ser3) residue of the proghrelin peptide is then esterified by an octanoic acid to form acyl ghrelin. It has been discovered that ghrelin O-acyl-transferase (GOAT) enzyme is responsible for the octanoylation of the proghrelin peptide (Yang et al., 2008). In addition to GOAT and PC 1/3, several lines of evidence also suggest that prohormone convertase 2 (PC2) and furin proteases may be involved in the post-translational processing of the preproghrelin protein (Zhang et al., 2005). This post-translational octanoyl modification is required for the biological activity of ghrelin (Hosoda et al., 2000). In contrast, the non-octanoylated form, in which the acylation of Ser3 does not occur, is known as the des-acyl form of ghrelin. Ser3 acylation is necessary for the GHS-R1A binding, thus, des-acyl ghrelin cannot bind to GHS-R1A and mediates its actions via alternate receptors which have yet to be determined (Leite-Moreira and Soares, 2007).

The human ghrelin gene on chromosome 3p25-26 encodes a 117-amino-acid preproghrelin protein (Gualillo et al., 2006) that undergoes post-translational modifications to generate the two major molecular forms of ghrelin; octanoylated (acyl) which comprises $<10 \%$ of circulating ghrelin, and des-n-octanoyl (des-acyl) ghrelin, which have different, and perhaps opposing functions in relation to energy homeostasis (Toshinai et al., 2006; Zhang et al., 2005). Although the des-acyl form of ghrelin comprises more than $90 \%$ of the total ghrelin released (Hosoda et al., 2000; Leite-Moreira and Soares, 2007), the acyl form activates the GHS-R1A to regulate several metabolic processes (Kojima et al., 1999) and promote food intake.

Des-acyl ghrelin, despite having the same precursor as acyl ghrelin, when administered intracerebroventricularly (ICV), has a tendency to decrease food intake and gastric emptying rate by acting on the paraventricular nucleus and the arcuate nucleus in the hypothalamus (Arc) in mice (Asakawa et al., 2005). Asakawa et al. (2005) also showed that mice overexpressing des-acyl ghrelin exhibited a decrease in food intake, body weight, fat pad mass, and linear growth. However, Toshinai et al. (2006) showed that during the light phase, des-acyl ghrelin stimulates feeding although to a lesser degree than total ghrelin, by activation of orexin neurons in the lateral hypothalamus in rodents (Toshinai et al., 2006). This difference may be due to the injection sites used by the two groups. Asakawa et al.'s (2005) administered des-acyl ghrelin into the third cerebral ventricle whereas Toshiniani et al. (2006) injected into the lateral cerebral ventricles. Moreover, no change in food intake occurred when des-acyl ghrelin was injected peripherally [intravenous] in Toshiniani et al 
(2006) whereas Asakawa et al. (2005) peripheral injections [intraperitoneal] decreased food intake.

Recently, obestatin, a 23-amino-acid peptide (as opposed to 28-amino-acid peptide ghrelin), was discovered at the preproghrelin C-terminal and found to originate from posttranslational processing of the preproghrelin peptide in a similar manner as ghrelin (Zhang et al., 2005). Obestatin was originally shown to have opposing action to acyl ghrelin, as cerebroventricular and peripheral injections of obestatin appeared to reduce food intake and weight in animals (Zhang et al., 2005). However, a number of investigators were unable to replicate these findings, and some found evidence opposite to its putative anorexigenic function (De Smet et al., 2007; Depoortere et al., 2008; Gourcerol et al., 2006; Gourcerol and Tache, 2007; Kobelt et al., 2008; Mondal et al., 2008; Nogueiras et al., 2007; Samson et al., 2007; Tremblay et al., 2007; Yamamoto et al., 2007). Moreover, some published in vitro results on obestatin have been retracted because of the replication and inconsistency issues (Chartrel et al., 2007; Lagaud et al., 2007; Zhang et al., 2005). Furthermore, Qader et al. (2008) reported that acyl ghrelin and obestatin both similarly stimulate glucagon secretion and inhibit pancreatic polypeptide secretion in rodents. However, more recently after a $24 \mathrm{~h}$ fast, albino ICR-CD1 mice had increased plasma levels of total ghrelin and obestatin with no change in preproghrelin mRNA levels and proghrelin -derived peptide secretion (Morash et al., 2010). In contrast, same study also showed that another strain, C57BL/6 mice -which have lower body weight and daily food intake than CD1 (Bachmanov et al., 2002; Atalayer and Rowland, 2009) had increased proghrelin mRNA expression, stomach acyl ghrelin peptide, and no change in plasma obestatin after a $24 \mathrm{~h}$ fast (Morash et al., 2010). Moreover ICV injection of obestatin did not change the $2 \mathrm{~h}$ rate of gastric emptying of a solid nutrient meal in rats (Chen et al 2012).

Since its discovery in 1999 by Kojima et al, ghrelin has been the focus of energy homeostasis and related clinical research. In addition to its main role in energy balance via the hypothalamus, ghrelin stimulation of the pituitary gland has been implicated in a number of biological processes, including immune function (Dixit et al., 2009; Nikolopoulos et al., 2010), hormone secretion (Egido et al., 2002; Messini et al., 2011), bone physiology (Kojima and Kangawa, 2005; Pemberton and Richards, 2008), memory retention (Carlini et al., 2002), cardiovascular function (Iglesias et al., 2007; Nagaya et al., 2001), and facilitation of digestion by increasing gastric acid production, gastric motility, and emptying (Bloomgarden, 2007; Levin et al., 2005). In the next sections, we will focus on the role of ghrelin as related to food intake, energy homeostasis, and appetite, which will underscore the relevance of ghrelin to eating disorder research.

\section{The Role of Ghrelin in Appetite and Body Weight Regulation}

Ghrelin has been shown to be a major orexigenic and adipogenic hormone, produced mainly in the gastrointestinal tract by the endocrine X/A-cells of the oxyntic glands of the mucosa and released to the blood stream (Choi et al., 2003; Sakata et al., 2009; Thompson et al., 2004). Although all the stimuli for ghrelin release have yet to be determined, numerous studies have shown circadian fluctuation in plasma ghrelin levels, with distinct increases before food intake, and rapid reductions after meals in both animals and humans. Studies have also shown that ghrelin is produced predominantly by the stomach, where its expression is highest (Kojima et al., 1999) and to a much lesser degree, in the hypothalamus (i.e. Arc and infundibular nucleus) and the pituitary gland (Howard et al, 1996).

Ghrelin also has central action following direct synthesis within the hypothalamus (De Vriese and Delporte, 2008; Wren et al., 2001). After its release into the blood stream, ghrelin reaches the Arc by crossing the blood-brain barrier and activates neuropeptide $\mathrm{Y}$ and 
agouti-related peptide-containing neurons (Guan et al., 2010). The stimulation of the Arc, has been shown to increase food intake (Berthoud, 2002) by increasing the number of meals rather than meal size (Chen et al., 2004; Murphy and Bloom, 2006). Another mechanism of a peripheral action via the vagal afferents as ghrelin receptors have been found on dorsal vagal complex (Holst and Schwartz, 2004). Additional ghrelin and growth hormone secretagogue receptors have been found in various peripheral organs (e.g. adrenal glands, pancreas, kidneys etc. (Date et al., 2000; Gnanapavan et al., 2002; van der Lely et al., 2004). Intravenous injections of acyl ghrelin increase appetite and food intake in humans. In a randomized double-blind cross-over study, Wren et al. (2001) reported a $28 \%$ dosedependent increase in food intake in healthy adults $(\mathrm{N}=9)$ following serial intravenous ghrelin (vs. saline) infusions. Also, although the congenital deletions of gene for either ghrelin or its receptor have been shown to fail to decrease food intake (Sun et al., 2003), they resulted in diet-induced obesity-resistant phenotypes in mice (Wortley et al., 2005; Zigman et al., 2005) which supports ghrelin's orexigenic role. Normal mice fed with a valine-deficient diet that induced severe anorexia ( $80 \%$ lower-than-average food intake), developed a significant hyperghrelinemia (Goto et al., 2010). Thus, ghrelin levels may be affected by the eating habits and/or depleted energy stores. Moreover, subcutaneous infusions of an agent that blocks ghrelin mediated activation of GHS-R1A in vivo was shown to promote weight loss in diet-induced obese mice (Shearman et al., 2006).

Administering ghrelin intracerebroventricularly in a dose-dependent manner has been shown to promote food intake and increase body weight more than peripheral ghrelin injections in both humans and rodents (Faulconbridge et al., 2003; Tschop et al., 2000). Unilateral injections of ghrelin into the dorsal vagal complex also induced hyperphagia in mice (Faulconbridge et al., 2003). Moreover, ghrelin's central nervous system (CNS) role has been linked to the reward-related aspect of eating behavior, as ghrelin stimulates dopamine neurons in the ventral tegmental area (VTA) and promotes dopamine turnover in the nucleus accumbens of the ventral striatum (Jerlhag et al., 2007), part of the major central reward pathway. Antagonism of ghrelin receptors in the VTA in mice decreased food intake (Jerlhag et al., 2007). Thus, ghrelin's effect on reward processing in the mesolimbic dopamine system may also contribute to its orexigenic action (Abizaid et al., 2006; Malik et al., 2008) in addition to its homeostatic energy balance role. Overall, these findings indicate that a key action for ghrelin is in the hypothalamic regulation of energy balance, which is a CNS mechanism.

As noted, plasma ghrelin levels rise prior to meals and decline rapidly postprandially (Carlson et al., 2009; English et al., 2002; Zwirska-Korczala et al., 2007), suggesting a role in preprandial hunger and meal initiation (Cummings et al., 2001). Moreover, postprandial suppression has been shown to be proportional to the caloric content of the meal (Callahan et al., 2004). The majority of studies examining ghrelin levels after Roux-en-Y-gastric bypass (RYGB) -a highly effective surgical intervention for obesity, show a decrease in postsurgical circulating ghrelin levels (Foschi et al., 2008; Fruhbeck et al., 2004; Garcia de la Torre et al., 2008; Lin et al., 2004; Morinigo et al., 2004). However, other results have also been found, such as an increase (Pardina et al., 2009; Sundbom et al., 2007; Vendrell et al., 2004) as well as no change following RYGB (Korner et al., 2009; Whitson et al., 2007), and higher ghrelin concentrations following gastric banding (Fruhbeck et al., 2004; Nijhuis et al., 2004; Schindler et al., 2004).

Conditions of higher energy stores (e.g., hyperglycemia, insulin resistance, obesity), on the other hand, are associated with lower ghrelin concentrations (Shiiya et al., 2002; Tschop et al., 2001). Obese individuals have lower fasting plasma ghrelin levels than their lean counterparts (Shiiya et al., 2002; Tschop et al., 2001). Despite this, the reduced ghrelin levels in overweight, obese, and insulin-resistant individuals do not appear to dampen their 
propensity to gain weight. The lower fasting ghrelin levels in obesity suggest a downregulation of ghrelin in response to overeating or to excess body weight. Higher ghrelin levels, on the other hand, have been observed during periods of fasting, hunger, or other conditions associated with lower energy stores, such as short-term starvation, cancer cachexia, as well as anorexia nervosa (Bloomgarden, 2007). These findings collectively demonstrate ghrelin's role as an orexigenic hormone involved in energy homeostasis and body weight regulation. Ghrelin's importance in eating behavior suggests a potential role in disordered eating behavior.

\section{The Role of Ghrelin in Eating Disorders}

According to the Diagnostic and Statistical Manual of Mental Disorders, $4^{\text {th }}$ edition, text revision (DSM IV-TR1), EDs may be categorized as anorexia nervosa (AN), bulimia nervosa (BN), and eating disorders not otherwise specified (EDNOS) (e.g., binge-eating disorder [BED], night-eating syndrome [NES]). Common features of EDs include aberrant eating patterns and excessive concern about body shape or weight. Although EDs have a multifactorial etiology and are commonly associated with psychological factors, we selectively describe recent findings concerning ghrelin levels in EDs, while acknowledging several contradictory findings (Table 1). In addition, we will summarize various reports on the genetic aspects of the association between ghrelin and EDs (Ando et al., 2007; Monteleone et al., 2006a). Finally, although animal models to explore physiology and central mechanisms are useful to advance our understanding of eating behavior, the models have limitations for ED research, e.g., an animal model of AN induced by restriction of food intake, would differ considerably from deliberate self-starvation. Thus, while including pertinent findings from animal models, we focus on human clinical studies.

\subsection{Anorexia Nervosa (AN)}

Anorexia Nervosa (AN) is a severe psychiatric disorder affecting about $0.9 \%$ of women and $0.3 \%$ of men (Hudson et al., 2007) and has the highest mortality rate of any mental disorder (Sullivan, 1995). It is characterized by a marked decrease in food intake from self-induced starvation, extreme weight loss (BMI $<18.5 \mathrm{~kg} / \mathrm{m}^{2}$ for U.S.A.), and reduced body fat. AN persons exhibit an obsessive fear about becoming overweight and excessive dietary restraint (restrictive subtype, AN-R) or may be in conjunction with binge eating and subsequent purging (binge-eating/purge subtype, AN-BP) or other forms of compensatory behavior (e.g., laxative misuse, excessive exercise) to avoid weight gain (Treasure et al., 2010).

DSM IV-TR criteria for AN are (APA, 2000):

- Refusal to maintain body weight at or above a minimally normal weight less than $85 \%$ of that expected for age and height.

- Intense fear of gaining weight or becoming fat, even though underweight.

- Disturbance in the way one's body weight or shape is experienced, undue influence of body weight or shape on self evaluation, or denial of the seriousness of the current low body weight.

- For postmenarcheal females, the absence of menstruation (at least 3 consecutive cycles).

Several studies have shown that AN individuals have higher levels of fasting plasma ghrelin than normal weight (NW) healthy controls (Monteleone et al., 2008; Nedvidkova et al., 2003; Otto et al., 2001; Tsenova et al., 2007). Monteleone et al. (2008) also reported increased circulating levels of obestatin and ghrelin as well as an increased ghrelin/obestatin ratio in AN than NW women. Moreover, in AN women, positive correlations emerged 
between the ghrelin/obestatin ratio and current body weight as well as BMI (Monteleone et al., 2008), suggesting an adaptive response to prolonged starvation. Although the controversy on the defined role of obestatin still exists, Monteleone et al. (2008) suggested that higher circulating levels of ghrelin and obestatin in underweight AN persons can be explained by an enhanced expression of the preproghrelin gene. This may lead to an enhanced production of ghrelin and obestatin, which results in higher ghrelin/obestatin ratio, producing a greater orexigenic signal in AN than NW women.

In addition, several researchers have compared nonpathological constitutionally thin (CT) women (BMI similar to AN) with AN patients. Tolle et al. (2003) showed that morning fasting plasma ghrelin concentrations in AN, compared to both normal weight (NW) and CT women, increased and remained higher for the rest of the day (measured every $4 \mathrm{~h}$ in a $24 \mathrm{~h}$ period) and subsequently normalized after renutrition. This suggests that in $\mathrm{AN}$, in addition to being body weight-dependent, ghrelin levels are affected by acute nutritional status. During short-term fasting, for example, circulating ghrelin is known to increase independently of changes in body adiposity (Tschop et al., 2001). In conditions of higher energy stores, such as obesity and overeating, ghrelin levels decrease, whereas during fasting or in AN, ghrelin is up-regulated (Soriano-Guillen et al., 2004). It is likely that higher ghrelin levels in AN are adaptive responses to stimulate eating and thereby increase body weight and fat. In addition, although AN and CT women had similar BMIs, AN women still had significantly lower body fat than CT women. Thus, intermediate ghrelin levels in CT (compared to AN and NW) indicate that ghrelin levels may be inversely related to body fat. However, the circadian rhythm of ghrelin levels in CT women was comparable to that of NW controls and AN patients, with ghrelin levels peaking at night in all groups (Tolle et al., 2003). These findings suggest that altered levels of ghrelin may be a consequence of disordered eating rather than a cause for AN.

Differences in ghrelin levels among specific subtypes of AN have also been reported. An AN-R subgroup, compared to NW control, had higher levels of ghrelin (Janas-Kozik et al., 2007; Nakahara et al., 2007) and reduced growth hormone release following ghrelin administration. This may be due to AN individuals adapting to the higher (than normal) ghrelin levels (Broglio et al., 2004). Recently, Germain et al. (2010) measured the 24h circulating levels of plasma ghrelin and showed that the area under the curve (AUC) of acyl ghrelin levels was greater for AN-R than for controls, also AN-BP subgroup had lower AUC of acyl ghrelin levels than the AN-R or the control group (Germain et al., 2010). Germain et al. (2010) also measured the ratio of mean circadian plasma acyl ghrelin to total ghrelin, which was similar in AN-R and control women, but lower in AN-BP women. Also, Nedvidkova et al. (2003) reported no decrease in postprandial ghrelin levels in AN after a standardized breakfast or noncaloric fiber meal (Psyllium), whereas ghrelin levels significantly decreased in healthy controls after both meals.

Monteleone et al. (2008) however, found no difference between AN-BP and AN-R women in fasting plasma ghrelin, obestatin, or in the ghrelin/obestatin ratio. Other varied results have been reported: Troisi et al. (2005) found higher levels of fasting ghrelin in AN-R than in AN-BP, in contrast to Tanaka et al.'s (2003) findings of higher fasting plasma ghrelin in AN-BP than AN-R. Troisi, et al. (2005), however, combined data from the AN-BP and BN purging patients, who likely had higher BMIs, which could explain why the results differed from Tanaka et al. (2003). Tanaka's group replicated their results in a subsequent study and included a third AN subgroup, requiring emergency hospitalization (AN-E), who were unable to eat and had extreme weight loss (Tanaka et al., 2004). They showed that AN-E had higher fasting plasma ghrelin than AN-BP, and that AN-BP had higher levels than AN$\mathrm{R}$. The three AN groups also had gradually decreasing plasma ghrelin levels following inpatient treatment. At the end of the nutritional rehabilitation, AN-BP patients still showed 
higher plasma ghrelin values than the control group (Tanaka et al., 2004). Others have also shown that ghrelin levels in AN-R patients after treatment did not completely normalize (Janas-Kozik et al., 2007; Nakahara et al., 2007; Soriano-Guillen et al., 2004). A likely explanation is that AN individuals, despite rehabilitation, did not reach their target BMI, and thus still displayed higher ghrelin values than controls (Janas-Kozik et al., 2007; Nakahara et al., 2007; Soriano-Guillen et al., 2004). Consistent with this, circulating ghrelin normalized after a renutrition intervention regimen in adolescents with AN following a 25\% increase in BMI, which was their target goal (Soriano-Guillen et al., 2004; Tolle et al., 2003).

Moreover, Otto et al. (2001) (including AN-R and AN-BP) and Nedvidkova et al. (2003) (subtype unspecified) reported a negative correlation between BMI and fasting plasma ghrelin levels in AN females. Shiiya et al. (2002) reported negative correlations between $\mathrm{BMI}$ and fasting plasma ghrelin in AN, obese, and normal weight control groups, while others reported no correlations (Janas-Kozik et al., 2007; Tanaka et al., 2003). On the other hand, body fat rather than BMI may better explain ghrelin levels (Monteleone et al., 2008) as some of the groups who had contradictory results regarding the correlation between BMI and ghrelin, showed consistent results for body fat (Tanaka et al., 2002; Nedvidkova et al., 2003; Monteleone et al., 2003; Monteleone et al., 2005).

Although assays to distinguish between acyl and des-acyl ghrelin moieties have improved recently (Prudom et al., 2010), there are still conflicting findings. For example, Hotta et al. (2004) found lower fasting levels of acyl ghrelin in AN than controls and no correlations between fasting levels of acyl ghrelin and BMI using immunocomplex transfer-enzyme immunoassay (ICT-EIA). However, using enzyme-linked immunosorbent assay (ELISA) kits, Hotta et al. (2004) reported no difference in fasting levels of acyl ghrelin between AN and controls, and also no correlation between fasting acyl ghrelin levels and BMI. Opposite to this, when using a radioimmunoassay (RIA) kit, they observed significantly higher plasma levels of fasting acyl ghrelin, as well as des-acyl (ELISA kit), and total ghrelin (RIA kit) in AN than the controls, which all negatively correlated with BMI.

Moreover, postprandial ghrelin levels in patients with AN remain high after consumption of a $585 \mathrm{kcal}$ solid mixed meal ( $32.6 \mathrm{~g}$ fat, $17.6 \mathrm{~g}$ protein, $50 \mathrm{~g}$ carbohydrate) and do not fall even two hours after meal consumption (Nedvidkova et al. 2003), whereas $250 \mathrm{ml}$ fluid meal of $250 \mathrm{kcal}$ ( $8.3 \mathrm{~g}$ fat, $9.4 \mathrm{~g}$ protein, $34.4 \mathrm{~g}$ carbohydrate) (Otto et al. 2005) as well as a $400 \mathrm{kcal}$ (10.4 g fat, $19.2 \mathrm{~g}$ protein, and $54.2 \mathrm{~g}$ carbohydrate) standard test meal (Nakahara et al. 2007) suppressed plasma ghrelin in AN. One study using RIA reported that fasting plasma acyl ghrelin levels were higher in AN than the controls and remained high after an oral glucose tolerance test (OGTT) $(75 \mathrm{~g} / 225 \mathrm{ml}$ glucose solution) (Nakai et al., 2003). Similarly, Misra et al. (2005) using an RIA kit reported that fasting plasma ghrelin levels were higher in AN adolescents than healthy controls $(\mathrm{p}<0.01)$ and remained higher following oral glucose ( $100 \mathrm{~g}$ glucose ingested over $10 \mathrm{~min})$ at $30 \mathrm{~min}(\mathrm{p}=0.0002)$ and 60 $\min (\mathrm{p}=0.008)$. In addition, plasma acyl ghrelin after an intravenous infusion of $500 \mathrm{ml}$ of $10 \%$ glucose solution displayed suppression in both AN and controls using ICT-EIA or ELISA kits, whereas des-acyl ghrelin (ELISA kit) did not decrease after glucose infusions in AN patients (Hotta et al., 2004). Although similar results on postprandial ghrelin levels have been reported, studies not differentiating the active and inactive forms of ghrelin make it difficult to interpret the findings.

Lastly, the role of genetic factors related to the ghrelin gene associated with the EDs is under active investigation. Twin and family trio (father, mother, child) studies as well as casecontrol designs have shown that genetic factors play a role in the etiology of AN. The three preproghrelin gene single nucleotide polymorphisms (SNPs), Leu72Met, Gln90Leu, and Arg51Gln, are thought to be associated with a tendency to develop EDs (Dardennes et al., 2007). The Leu72Met variant of the preproghrelin gene and an excess of transmission of the 
Gln90Leu72 preproghrelin/obestatin haplotype have been reported in patients with AN-BP (Dardennes et al., 2007). In addition, a genetic polymorphism was reported in the Leu72Met SNP of the preproghrelin gene and Ala67Thr SNP of the AgRP (Thr67AGRP) gene which was shown to be preferentially transmitted for the trios with a bingeing/purging proband for AN (Vink et al., 2001). These genetic findings support the hypothesis that polymorphisms in ghrelin and AgRP genes may lead to susceptibility to AN, especially the binge/purge subtype (Dardennes et al., 2007). However, some studies report no significant differences in the frequencies of the Leu72Met, Arg51Gln (Monteleone et al., 2006a), and Gln90Leu ghrelin gene variants among AN or BN patients (Cellini et al., 2006; Miyasaka et al., 2006; Monteleone et al., 2006a), but these studies did not distinguish among different clinical subtypes of AN. Higher baseline plasma ghrelin levels, BMI, body adiposity, waist circumference, and self-rating scores in the "drive for thinness" and "body dissatisfaction" subscales of the Eating Disorder Inventory II (EDI-2) have been reported in young healthy women carrying the $\mathrm{C}$ allele at the $3056 \mathrm{~T}-\mathrm{C}$ SNP rather than the TT genotypes (Ando et al., 2007; Ando et al., 2010). The $\mathrm{C}$ allele is also associated with a higher probability and rate of recovery of normal body weight from AN-R (Ando et al., 2007; Ando et al., 2010). Overall, although polymorphisms in the preproghrelin/ghrelin gene have been previously identified in relation to obesity (Korbonits et al., 2002); no candidate genes for ghrelin that predispose people to EDs have been identified to date.

\subsection{Bulimia Nervosa (BN)}

Bulimia nervosa is characterized by recurrent episodes of binge eating followed by inappropriate compensatory behaviors to avoid weight gain. The binge eating and inappropriate compensatory behavior both occur, on average, at least twice a week for 3 months. Self evaluation is unduly influenced by body shape and weight.

DSM IV-TR (APA, 2000) describes the recurrent episodes of binge eating by:

- Eating, in a discrete period of time (e.g., within any 2-hour period), an amount of food that is definitely larger than most people would eat during a similar period of time and under similar circumstances.

- A sense of lack of control over eating during the episode (such as a feeling that one cannot stop eating or control what or how much one is eating).

and describes the recurrent inappropriate compensatory behavior to prevent weight gain by:

- Self-induced vomiting and misuse of laxatives diuretics, enemas, or other medications (purging subtype, BN-P), fasting and overexercising (nonpurging subtype, $\mathrm{BN}-\mathrm{NP})$.

Food intake is highly variable in $\mathrm{BN}$, and unlike patients with AN, most patients with BN tend to be of normal weight (Weltzin et al., 1991). Many studies have been conducted to investigate psychological and cognitive factors related to BN (Rowe et al., 2010; Woldt et al., 2010). Several physiological factors associated with BN have also been described, such as enlarged stomach capacity (Geliebter et al., 1992), rare cardiac complications (Suri et al., 1999), stomach ruptures (Abdu et al., 1987), and neurochemical alterations (Kaye et al., 2005). However, neurohumoral pathogenesis associated with BN has not been adequately studied.

Tanaka et al. (2002) showed that mean fasting (08:00 am) plasma ghrelin concentration in female BN subjects were significantly higher than controls with similar BMIs. They also showed that ghrelin levels in both groups were negatively correlated with BMI and body fat percentage. Elevated basal plasma ghrelin levels in BN patients were also reported by Kojima et al. (2005). In addition to fasting ghrelin, the postprandial ghrelin decline was 
found to be significantly blunted in BN women compared to controls (Kojima et al., 2005; Monteleone et al., 2005b). On the other hand, Nakazato et al. (2004) reported that ghrelin levels did not differ significantly between healthy controls and female BN patients. In addition, they reported no significant correlation between ghrelin levels and BMI, in contrast to the Tanaka et al. (2002) study. One possible explanation for the differential reports would be that Nakazato et al. (2004) measured serum ghrelin levels randomly between 11:00 am12:00 pm (non-fasting) instead of fasting plasma ghrelin that was measured by Tanaka et al. (2002). Peripheral ghrelin has been assayed from serum as well as plasma; however Espelund et al. (2003) showed that serum yielded higher results than heparinized plasma EDTA (Ethylenediaminetetraacetic acid) plasma, and EDTA-plasma with aprotinin $(\mathrm{p}<0.05)$. Thus, preference for use of plasma versus serum may affect levels obtained in different studies. Nevertheless, Monteleone et al. (2008) measuring fasting plasma ghrelin as did Tanaka et al. (2002), found results similar to Nakazato et al. (2004): no difference in plasma ghrelin between BN women and controls, and no correlation between BMI and ghrelin. It should be noted that Monteleone et al. (2008) used ELISA whereas Tanaka et al. (2002) used RIA to measure ghrelin. This could also help account for the discrepancy because the sensitivity between the two methods may vary and detect different fragments of ghrelin (Hotta et al., 2004). Monteleone et al. (2010) when using RIA, noted enhanced fasting plasma ghrelin increase after a modified sham feeding (chewing and spitting each bite over the $15 \mathrm{~min}$ time period) in $\mathrm{BN}$ patients, which may result in greater potentiation of peripheral hunger signals in $\mathrm{BN}$ compared to healthy controls. They hypothesize that BN patients have greater ghrelin secretion in the cephalic phase of vagal stimulation, which might contribute to their binge eating episodes. These findings are similar to those in patients with binge-eating disorder (BED) (Monteleone et al., 2003). Thus, when using the RIA kits, Monteleone et al. (2010) reported similar results to that of Tanaka et al. (2002) study showing higher fasting plasma ghrelin levels in BN than controls. This indicates that the difference between Nakazato et al.'s (2004) and these two studies may be due to the nonfasting ghrelin measured by Nakazato et al.

Analyzing the ghrelin levels of the two subtypes of $\mathrm{BN}$ (purging vs. nonpurging) separately has also been done. A study by Germain et al. (2010) measured ghrelin levels in patients with purging type $\mathrm{BN}(\mathrm{BN}-\mathrm{P})$ at twelve time points during a $24 \mathrm{~h}$ period, which included three standard meals at $0815 \mathrm{~h}(400 \mathrm{kcal}), 1215 \mathrm{~h}(800 \mathrm{kcal})$, and $1915 \mathrm{~h}(800 \mathrm{kcal})$ after an overnight fast, and obtained an area under the curve (AUC) for analysis. In contrast to the above reports (Tanaka et al., 2002; Nakazato et al.,2004; Montelone et al., 2008; Montelone et al., 2010), Germain et al. (2010) found that patients with BN-P had significantly lower AUC total and acyl ghrelin levels than healthy controls. However, in the above reports, the different subtypes of BN were not separated. Although this may help explain the discrepancy, a study by Troisi et al. (2005) reported no difference in fasting plasma ghrelin between the purging and nonpurging $\mathrm{BN}$ (BN-P vs. BN-NP) subtypes, suggesting that subtype may not adequately explain the different findings (Tanaka et al., 2002; Nakazato et al., 2004; Montelone et al., 2008; Montelone et al., 2010). Another possible explanation may be that the above studies reported fasting plasma ghrelin, whereas Germain et al. (2010) used AUC for $24 \mathrm{~h}$ circulating plasma ghrelin which also reflects meal intake and circadian patterns. Germain et al. (2010) also showed that BN-P patients have lower AUC 24h circulating plasma obestatin and mean circulating plasma acyl-to-total ghrelin ratio than healthy controls. They additionally found that the mean circulating levels of obestatin-toacyl ghrelin ratio was higher in BN patients than in controls. In a more recent study, Sedlackova et al. (2011) obtained similar results namely that the ratio of fasting plasma ghrelin-to-obestatin was lower in BN compared to the control group. Monteleone et al. (2008) however, found no difference in the ratio of ghrelin-to-obestatin, between BN and control women. 
Besides comparing $\mathrm{BN}$ to healthy controls, comparing $\mathrm{BN}$ to $\mathrm{AN}$ patients is also informative. Troisi et al. (2005) found that women with AN had significantly higher fasting plasma ghrelin level than BN, BED, and control women. They also categorized the different subtypes of $\mathrm{AN}$ and $\mathrm{BN}$, and showed that AN-R had higher ghrelin levels than BN patients regardless of the $\mathrm{BN}$ subtype. They reported no difference in fasting plasma ghrelin concentrations between the BN subtypes (BN-P vs. BN-NP). The restricting-type AN (AN$\mathrm{R})$ women had higher fasting plasma ghrelin levels than patients with binge-eating/purging behavior, including those with both AN (AN-BP) and BN (BN-P). Grouping AN-BP and BN-P together may be a limitation, but Germain et al. (2010) found no difference between the AN-BP and BN-P in $24 \mathrm{~h}$ levels of plasma ghrelin. Overall, these studies showed that patients displaying binge-eating/purging subtypes for both AN and BN (AN-BP and BN-P) had lower ghrelin levels than AN-R patients. Although the lower ghrelin levels in AN-BP and BN-P may reflect a higher energy store than in AN-R, BMI, tends to be similar between $\mathrm{AN}-\mathrm{BP}$ and AN-R, and yet ghrelin was significantly lower in AN-BP than BN-P (Monteleone et al., 2003). Therefore, ghrelin level differences in AN-R versus AN-BP patients may be an indicator of acute nutritional status reflecting lower caloric intake rather than energy store (Tolle et al., 2003). It has also been shown that ghrelin concentration and secretion were negatively correlated with insulin resistance (HOMA-IR) (Misra et al., 2005) which is an indication of reduced glucose uptake. Nakahara et al. (2007) also showed that HOMA-R score in AN patients was significantly lower $(\mathrm{p}<0.05)$ than controls which was normalized after treatment. Thus, taken together, ghrelin levels are predicted by markers of acute nutritional status in ED patients.

Ghrelin gene polymorphisms may be associated with vulnerability for BN. Several studies have examined the distribution of ghrelin gene variants in BN. The frequency of the CC type of the GHS-R gene (171T/C) was significantly higher in BN than in healthy controls and may be a risk factor for BN (Miyasaka et al., 2006). In addition, preferential transmission of the ghrelin Glu90Leu72Arg51 haplotype has been suggested as another predisposing factor for BN (Cellini et al., 2006). Ando et al. (2010) reported a more frequent $\mathrm{C}$ allele at the 3056 T-C SNP (CC and TC genotypes) in intron 3, and a more frequent Met allele at the Leu72Met SNP of the ghrelin gene in BN-BP. However, these studies did not confirm an established genetic variant as a risk factor for BN. Studies including larger sample sizes, different ethnic backgrounds, and extensive screening for comorbidities are needed.

\subsection{Binge eating disorder (BED)}

Binge eaters consume excessive food quantities in short time periods, with loss of control and lack of compensatory behaviors. The high prevalence of BED (Franko et al., 2012), which is more common in overweight and obese individuals (Yanovski et al., 1993), has led to its expected new status as a distinct clinical diagnostic entity in the DSM V (Keel et al.). However, it is currently categorized as EDNOS in DSM IV-TR.

Following are the criteria for BED in DSM IV-TR (APA, 2000):

- Recurrent episodes of binge eating. An episode of binge eating is characterized by both of the following:

1. eating, in a discrete period of time (within any $2 \mathrm{~h}$ period), an amount of food that is definitely larger than most people would eat in a similar period of time under similar circumstances

2. a sense of lack of control over eating during the episode (a feeling that one cannot stop eating or control what or how much one is eating)

- The binge-eating episodes are associated with three (or more) of the following: 
1. eating much more rapidly than normal

2. eating until feeling uncomfortably full

3. eating large amounts of food when not feeling physically hungry

4. eating alone because of being embarrassed by how much one is eating

5. feeling disgusted with oneself, depressed, or very guilty after overeating

- Marked distress regarding binge eating is present.

- The binge eating occurs, on average, at least 2 days a week for 6 months.

Researchers have investigated various genes and neuropeptides associated with BED to determine possible predictors of binge eating behavior. Higher ghrelin levels could help explain greater food intake, reduced fuel utilization, and subsequent weight gain in BED. Although one study showed that fasting and postprandial ghrelin levels did not differ between overweight/obese BED persons and BMI-matched controls (Munsch et al., 2009), the majority of studies report that plasma ghrelin concentrations are decreased in obese BED, which is contrary to the expected higher levels (Geliebter et al., 2005; Monteleone et al., 2005a; Troisi et al., 2005). Despite decreased ghrelin levels, there does not appear to be a reduced propensity to gain weight in BED. The lower ghrelin, as also seen in the obese relative to lean individuals, may be due to down-regulation of ghrelin release in response to overeating or excess body weight. The initial smaller decline in ghrelin following a meal has been noted in obese BED patients (Geliebter et al., 2005), and conceivably, the blunted postprandial decline in ghrelin levels may act to maintain hunger.

Ghrelin-encoding genes potentially may be contributing to BED. For example, Monteleone et al. (2006) assessed the 196G/A SNP of the human BDNF gene in BN and BED women and found no differences in gene variant frequencies between groups, yet persons with the 196G/A SNP as compared with196A/G and 196G/G genotypes, had greater frequency of binge eating episodes. Monteleone et al. also found greater expression of the Leu72Met ghrelin gene variant in obese and normal-weight persons with BED relative to healthy, normal weight women (Monteleone et al., 2007). The Leu72Met ghrelin gene may therefore be associated with a genetic susceptibility for BED (Monteleone et al., 2007), whereas the AA variant of the 196G/A SNP of the human BDNF gene may predispose individuals to higher frequency of binge eating (Monteleone et al., 2006b).

\subsection{Night eating syndrome (NES)}

Night eating syndrome (NES) is currently categorized as EDNOS in DSM IV-TR (APA, 2000); however there is a proposed upgrading of NES in DSM V NES is characterized by recurrent episodes of evening hyperphagia and nocturnal food intake that is not accounted for by BED, other EDs, or insomnia. NES is associated with significant distress and/or impairment in functioning. A small number of studies have assessed ghrelin levels in NES individuals. Allison et al. (2005) measured circulating ghrelin levels over 25 hours in obese NES and found that ghrelin was significantly lower in the NES group compared to healthy, obese controls from 1 am to $9 \mathrm{am}$. Studies have shown that ghrelin helps regulate the sleepwake cycle to promote sleep (Schussler et al., 2006; Steiger, 2007), and lower levels may contribute to the tendency for frequent awakenings in persons with NES. However, another group found no significant difference in nocturnal ghrelin concentrations in women with and without NES (Goel et al., 2009), but the ghrelin secretory pattern was phase-advanced by 5.2 hours, suggesting a dissociation between the circadian rhythm associated with food intake and the sleep-wake cycle. Elevated ghrelin levels in a NES patient before and also after 8 weeks of treatment, relative to normal weight controls, were reported by Rosenhagen et al. (2005), suggesting that higher ghrelin levels may disrupt sleep due to increased hunger 
(Rosenhagen et al., 2005). Collectively, these findings suggest that variations in nocturnal ghrelin secretion may contribute to the onset or maintenance of NES (O'Reardon et al., 2005). A ghrelin concentration above a certain threshold may stimulate hunger vs. sleep in humans (Schuessler et al., 2005), and abnormal elevations in nocturnal ghrelin secretion could increase the risk of developing NES.

\subsection{Prader-Willi syndrome (PWS)}

Prader-Willi syndrome (PWS) is a genetic form of obesity, associated with the loss or silencing of several paternal genes in the q11-13 region of chromosome 15. Infants with PWS typically exhibit poor feeding and failure to thrive, with the hallmark hyperphagia beginning between the ages of 18 months and 6 years. PWS is characterized by endocrine disturbances, neurocognitive disabilities, and severe hyperphagia leading to obesity. Although not classified as an eating disorder, PWS merits inclusion in this review because of the coincidence of obesity, hyperphagia, and abnormal ghrelin levels in this disorder (Cummings et al., 2002).

Moreover, PWS is included in DSM IV-TR (APA, 2000) in Axis I Diagnosis of Personality Change Due to a Medical Condition as follows:

- Overeating of typical food

- Eating atypical food (frozen, raw, spoiled food or pet food)

- Sneaking food in the home

- Night time foraging in the home

- Arguing or manipulating to get food

- Throwing tantrums to get food

- Opportunistic food theft (shoplifting from a store or stealing food from school or work)

- Planned food foraging expeditions in the neighborhood or community

- Nonconfrontational, invasive food access (breaking locks on cabinets, refrigerator or freezer, trespassing)

- Confrontational food access (using verbal or physical threats or actual aggression to access food)

Total ghrelin levels in PWS individuals are elevated relative to healthy as well as adipositymatched controls, in both the fasting and fed states. This elevated ghrelin level has been postulated to be a cause for the hyperphagia and resultant obesity associated with PWS. PWS individuals experience markedly reduced meal-induced suppression of hunger, as compared with adiposity-matched and lean controls (Purtell et al., 2011). However, another recent study found that the childhood transition from poor feeding to hyperphagia is not associated with a change in ghrelin levels (Goldstone et al., 2012). Also not all PWS individuals have increased ghrelin. Furthermore, suppression of ghrelin release by octreotide does not appear to reduce hyperphagia, appetite, or body adiposity (De Waele et al., 2008; Haqq et al., 2003; Tan et al., 2004). However, octreotide would have suppressed all hormonal output, including the satiety inducing gut peptides, which might have canceled the effects on ghrelin. Exenatide, an incretin analogue that suppresses appetite, increases pancreatic insulin secretion, and has been approved for the treatment of type 2 diabetes mellitus, increased satiety in PWS individuals, without affecting ghrelin levels. The data from these studies indicates that while ghrelin appears to play a role in the hyperphagia and resulting obesity of PWS, more investigation is required before causation can be established. 


\section{Discussion}

The etiological factors of ED may not solely be psychological and include the interplay of genetic and environmental factors. Although the causal direction remains unclear, metabolic and endocrine alterations in EDs have been reported indicating altered ghrelin levels. Some inconsistencies (Table 2) between studies by different groups may be due to methodological differences, sample differences such as, duration of illness, sample size, ED subtypes, serum vs. plasma ghrelin, acyl vs. des-acyl vs. total ghrelin, age, and BMI. Nevertheless, one common finding is the inverse relation between BMI and ghrelin levels, and there is even more consistency across studies when percentage or absolute body fat is used rather BMI.

Thus, although genetic factors have been reported on ghrelin levels in patients with EDs, it is possible that altered ghrelin levels (relative to the healthy controls) may be a results of an under/overweight status of those with these disorders. Studies show that after a BMI increase of $\sim 15 \%$ following treatment of AN patients, circulating and fasting ghrelin levels decreased towards normal (Otto et al. 2001; Janas-Kozik et al., 2007; respectively). Moreover, following treatment, patients with AN who gain more weight exhibit a faster insulin and glucose responses than patients who gain less weight (Yasuhara et al., 2003). It is known that ghrelin levels are suppressed by glucose administration in healthy humans (Shiya et al., 2002). Thus, examining other metabolic hormones that are regulated by body fat, such as leptin (Rowland and Morien, 1996; Berthoud, 2002) is also informative.

It is known that ghrelin and leptin exert opposite metabolic actions in relation to energy homeostasis (Berthoud, 2002), and that ghrelin is orexigenic, whereas leptin is anorexigenic. In conditions of positive energy balance such as obesity, overeating (except PWS), plasma ghrelin levels decrease (Soriano-Guillen et al., 2004), whereas plasma leptin levels move in the opposite direction and increase (Rowland and Morien, 1996). On the other hand, during fasting or in AN, which entails a lower body fat, leptin is down-regulated (Miljic et al., 2006) while ghrelin is up-regulated (Soriano-Guillen et al., 2004). Monteleone et al., (2008) showed that AN patients had lower leptin and higher ghrelin than healthy controls whereas $\mathrm{BN}$ had ghrelin and leptin levels similar to healthy controls. They also found no difference in plasma levels of leptin, ghrelin and BMI between AN-R and AN-BP patients. However, findings from studies in BED patients suggest that binge eating may lead to a decrease in ghrelin levels despite similar BMI. Moreover, caloric restriction may have a direct effect beyond body energy stores in increasing ghrelin as in AN-R. However, purging which induces a lower energy store may also stimulate ghrelin. Nevertheless, AN-BP patients had higher fasting ghrelin levels than BN-P, which is likely due to weight differences. It would be worthwhile to examine ghrelin over a period of time following purging in AN-BP vs. BN-P patients to differentiate the effect of purging from body weight. It is likely that higher ghrelin levels in AN are adaptive responses to a state of negative energy store, to induce eating and increase body weight and fat. Normalizing or partially normalizing circulating ghrelin levels following weight gain via renutrition in AN supports the hypothesis that altered levels of ghrelin are consequences of the disorder. Reduced food intake in patients AN with low BMI and body fat as well as chronically higher ghrelin levels may also reflect insensitivity to the effects of ghrelin (Misra et al., 2005). Several studies have shown that patients with AN had reduced growth hormone secretion after ghrelin administration than the controls which may be an adaptation to the high ghrelin levels (Broglio et al., 2004; Miljic et al., 2006). Future research should examine the relationship among hormones associated with body fat, including ghrelin and leptin.

To improve consistency across studies, researchers should examinedifferent moieties of ghrelin in their hormone analyses. The blood collection time and methods, including the hormone assay kits used are also relevant to replicate results. In addition, the subtypes of 
EDs should be considered separately, as their phenotypes and genotypes may differ. Investigation of genetic markers associated with different subtypes of EDs (Dardennes et al., 2007) may also be helpful because initial ED diagnosis may vary over time. For example, some reports have noted that $62 \%$ of patients initially diagnosed with AN-R are later diagnosed as AN-BP, and 21-36\% are later diagnosed as BN (Nishimura et al., 2008). It has been suggested that preproghrelin gene expression may be altered by energy store imbalance over prolonged periods, and genetic polymorphisms may therefore be potential predictors of subtypes as well as changes over time in EDs. Since obestatin and ghrelin are produced from the same preproghrelin gene, regardless of the obestatin's questioned function, measuring obestatin levels and obestatin to ghrelin ratio may help discriminate between EDs. Few recent studies have reported e obestatin levels in patients with EDs (Germain et al., 2010; Sedlackova et al., 2011) and most reported total obestatin, that is both amidated and nonamidated peptide. Similar to the acylation of the peptide, amidation of obestatin is necessary for its bioactivity (Monteleone et al., 2008).

The duration of the ED may contribute to the degree of metabolic alterations and endocrinological changes, resulting in inconsistency between different studies. For instance, in AN the postprandial decrease in ghrelin has been reported by several groups (Nakai et al., 2003; Nakahara et al., 2007) while others reported that the postprandial response is impaired (Nedvidkova et al., 2003). All of these studies are missing the information about duration of the illness. Thus, another possible factor contributing to the inconsistency among these studies may be variation in the duration of illness.

In conclusion, the key factor influencing ghrelin levels may be the under or overweight status (Tolle et al., 2003; Misra et al., 2005) in EDs in humans. Thus, ghrelin dysregulation could be involved in the maintenance of EDs, but without being a causal factor. The complex interplay among central and peripheral signals involved in normal eating behavior, may be even more complex in its disordered forms. Although ghrelin has been a topic of ED research for over 10 years, the causal direction has still not been resolved. Future research on ED's should examine the interplay of multiple food intake signals including ghrelin in longitudinal and treatment studies as well as considering the aforementioned methodological issues.

\section{Acknowledgments}

We thank Laura Kolbe for her exemplary editing. Supported in part by NIH R01DK080153.

\section{References}

Abdu RA, Garritano D, Culver O. Acute gastric necrosis in anorexia nervosa and bulimia. Two case reports. Arch Surg. 1987; 122:830-2. [PubMed: 3592974]

Abizaid A, Liu ZW, Andrews ZB, Shanabrough M, Borok E, Elsworth JD, et al. Ghrelin modulates the activity and synaptic input organization of midbrain dopamine neurons while promoting appetite. $\mathrm{J}$ Clin Invest. 2006; 116:3229-39. [PubMed: 17060947]

Allison KC, Ahima RS, O'Reardon JP, Dinges DF, Sharma V, Cummings DE, Heo M, Martino NS, Stunkard AJ. Neuroendocrine Profiles associated with energy intake, sleep, and stress in the night eating syndrome. JCEM. 2005; 90(11):6214. [PubMed: 16131578]

Altman SE, Shankman SA. What is the association between obsessive-compulsive disorder and eating disorders? Clin Psychol Rev. 2009; 29:638-46. [PubMed: 19744759]

Ando T, Ichimaru Y, Konjiki F, Shoji M, Komaki G. Variations in the preproghrelin gene correlate with higher body mass index, fat mass, and body dissatisfaction in young Japanese women. Am $\mathrm{J}$ Clin Nutr. 2007; 86:25-32. [PubMed: 17616759] 
Ando T, Komaki G, Nishimura H, Naruo T, Okabe K, Kawai K, et al. A ghrelin gene variant may predict crossover rate from restricting-type anorexia nervosa to other phenotypes of eating disorders: a retrospective survival analysis. Psychiatr Genet. 2010; 20:153-9. [PubMed: 20421852]

American Psychiatric Association. Diagnostic and statistical manual of mental disorders. 4. Washington, DC: Author; 2000. text rev

Asakawa A, Inui A, Fujimiya M, Sakamaki R, Shinfuku N, Ueta Y, et al. Stomach regulates energy balance via acylated ghrelin and desacyl ghrelin. Gut. 2005; 54:18-24. [PubMed: 15591499]

Atalayer D, Rowland NE. Comparison of C57BL/6 and DBA/2 mice in food motivation and satiety. Physiol Behav. 2010; 99(5):679-83. [PubMed: 20138902]

Bachmanov AA, Reed DR, Beauchamp GK, Tordoff MG. Food intake, water intake and drinking spout side preference of 28 mouse strains. Behav Genet. 2002; 32:435-43. [PubMed: 12467341]

Berthoud HR. Multiple neural systems controlling food intake and body weight. Neurosci Biobehav Rev. 2002; 26:393-428. [PubMed: 12204189]

Bloomgarden ZT. Gut hormones, obesity, polycystic ovarian syndrome, malignancy, and lipodystrophy syndromes. Diabetes Care. 2007; 30:1934-9. [PubMed: 17596508]

Broglio F, Gianotti L, Destefanis S, Fassino S, Abbate Daga G, Mondelli V, et al. The endocrine response to acute ghrelin administration is blunted in patients with anorexia nervosa, a ghrelin hypersecretory state. Clin Endocrinol (Oxf). 2004; 60:592-9. [PubMed: 15104562]

Callahan H, Cummings D, Pepe M, Breen P, Matthys C, Weigle D. Postprandial suppresion of plasma ghrelin level is proportional to ingested caloric load but does not predict intermeal interval in humans. J Clin Endocrinol Metab. 2004; 89:6. [PubMed: 14715817]

Carlini VP, Monzon ME, Varas MM, Cragnolini AB, Schioth HB, Scimonelli TN, et al. Ghrelin increases anxiety-like behavior and memory retention in rats. Biochem Biophys Res Commun. 2002; 299:739-43. [PubMed: 12470640]

Carlson JJ, Turpin AA, Wiebke G, Hunt SC, Adams TD. Pre- and post- prandial appetite hormone levels in normal weight and severely obese women. Nutr Metab (Lond). 2009; 6:32. [PubMed: 19671157]

Cellini E, Nacmias B, Brecelj-Anderluh M, Badia-Casanovas A, Bellodi L, Boni C, et al. Case-control and combined family trios analysis of three polymorphisms in the ghrelin gene in European patients with anorexia and bulimia nervosa. Psychiatr Genet. 2006; 16:51-2. [PubMed: 16538179]

Chartrel N, Alvear-Perez R, Leprince J, Iturrioz X, Reaux-Le Goazigo A, Audinot V, et al. Comment on "Obestatin, a peptide encoded by the ghrelin gene, opposes ghrelin's effects on food intake". Science. 2007; 315:766. author reply 66. [PubMed: 17289961]

Chen HY, Trumbauer ME, Chen AS, Weingarth DT, Adams JR, Frazier EG, et al. Orexigenic action of peripheral ghrelin is mediated by neuropeptide $\mathrm{Y}$ and agouti-related protein. Endocrinology. 2004; 145:2607-12. [PubMed: 14962995]

Chen CY, Lee WJ, Chong K, Lee SD, Liao YD. Impact of intracerebroventricular obestatin on plasma acyl ghrelin, des-acyl ghrelin and nesfatin-1 levels, and on gastric emptying in rats. Mol Med Report. 2012; 6(1):191-6. [PubMed: 22562076]

Choi K, Roh SG, Hong YH, Shrestha YB, Hishikawa D, Chen C, et al. The role of ghrelin and growth hormone secretagogues receptor on rat adipogenesis. Endocrinology. 2003; 144:754-9. [PubMed: 12586750]

Cummings DE, Clement K, Purnell JQ, Vaisse C, Foster KE, Frayo RS, et al. Elevated plasma ghrelin levels in Prader Willi syndrome. Nat Med. 2002; 8:643-4. [PubMed: 12091883]

Cummings DE, Purnell JQ, Frayo RS, Schmidova K, Wisse BE, Weigle DS. A preprandial rise in plasma ghrelin levels suggests a role in meal initiation in humans. Diabetes. 2001; 50:1714-9. [PubMed: 11473029]

Dardennes RM, Zizzari P, Tolle V, Foulon C, Kipman A, Romo L, et al. Family trios analysis of common polymorphisms in the obestatin/ghrelin, BDNF and AGRP genes in patients with Anorexia nervosa: association with subtype, body-mass index, severity and age of onset. Psychoneuroendocrinology. 2007; 32:106-13. [PubMed: 17197106]

Date Y, Kojima M, Hosoda H, Sawaguchi A, Mondal MS, Suganuma T, et al. Ghrelin, a novel growth hormone-releasing acylated peptide, is synthesized in a distinct endocrine cell type in the 
gastrointestinal tracts of rats and humans. Endocrinology. 2000; 141:4255-61. [PubMed: 11089560]

De Smet B, Thijs T, Peeters TL, Depoortere I. Effect of peripheral obestatin on gastric emptying and intestinal contractility in rodents. Neurogastroenterol Motil. 2007; 19:211-7. [PubMed: 17300291]

De Vriese C, Delporte C. Ghrelin: a new peptide regulating growth hormone release and food intake. Int J Biochem Cell Biol. 2008; 40:1420-4. [PubMed: 17544318]

De Waele K, Ishkanian SL, Bogarin R, Miranda CA, Ghatei MA, Bloom SR, et al. Long-acting octreotide treatment causes a sustained decrease in ghrelin concentrations but does not affect weight, behaviour and appetite in subjects with Prader-Willi syndrome. Eur J Endocrinol. 2008; 159:381-8. [PubMed: 18603572]

Depoortere I, Thijs T, Moechars D, De Smet B, Ver Donck L, Peeters TL. Effect of peripheral obestatin on food intake and gastric emptying in ghrelin-knockout mice. Br J Pharmacol. 2008; 153:1550-7. [PubMed: 18204478]

Dixit VD, Yang H, Cooper-Jenkins A, Giri BB, Patel K, Taub DD. Reduction of T cell-derived ghrelin enhances proinflammatory cytokine expression: implications for age-associated increases in inflammation. Blood. 2009; 113:5202-5. [PubMed: 19324904]

Egido EM, Rodriguez-Gallardo J, Silvestre RA, Marco J. Inhibitory effect of ghrelin on insulin and pancreatic somatostatin secretion. Eur J Endocrinol. 2002; 146:241-4. [PubMed: 11834435]

English PJ, Ghatei MA, Malik IA, Bloom SR, Wilding JP. Food fails to suppress ghrelin levels in obese humans. J Clin Endocrinol Metab. 2002; 87:2984. [PubMed: 12050284]

Erlanson-Albertsson C. Appetite regulation and energy balance. Acta Paediatr Suppl. 2005; 94:40-1. [PubMed: 16175806]

Espelund U, Hansen TK, Orskov H, Frystyk J. Assessment of ghrelin. APMIS Suppl. 2003; 109:140_ 145. [PubMed: 12874966]

Faulconbridge LF, Cummings DE, Kaplan JM, Grill HJ. Hyperphagic effects of brainstem ghrelin administration. Diabetes. 2003; 52:2260-5. [PubMed: 12941764]

Foschi D, Corsi F, Colombo F, Vago T, Bevilaqua M, Rizzi A, et al. Different effects of vertical banded gastroplasty and Roux-en-Y gastric bypass on meal inhibition of ghrelin secretion in morbidly obese patients. J Invest Surg. 2008; 21:77-81. [PubMed: 18340624]

Frank GK, Bailer UF, Henry SE, Drevets W, Meltzer CC, Price JC, et al. Increased dopamine D2/D3 receptor binding after recovery from anorexia nervosa measured by positron emission tomography and [11c]raclopride. Biol Psychiatry. 2005; 58:908-12. [PubMed: 15992780]

Franko DL, Thompson-Brenner H, Thompson DR, Boisseau CL, Davis A, Forbush KT, et al. Racial/ ethnic differences in adults in randomized clinical trials of binge eating disorder. J Consult Clin Psych. 2012; 80(2):186-95.

Fruhbeck G, Rotellar F, Hernandez-Lizoain JL, Gil MJ, Gomez-Ambrosi J, Salvador J, et al. Fasting plasma ghrelin concentrations 6 months after gastric bypass are not determined by weight loss or changes in insulinemia. Obes Surg. 2004; 14:1208-15. [PubMed: 15527636]

Garcia de la Torre N, Rubio MA, Bordiu E, Cabrerizo L, Aparicio E, Hernandez C, et al. Effects of weight loss after bariatric surgery for morbid obesity on vascular endothelial growth factor-A, adipocytokines, and insulin. J Clin Endocrinol Metab. 2008; 93:4276-81. [PubMed: 18713823]

Geliebter A, Gluck ME, Hashim SA. Plasma ghrelin concentrations are lower in binge-eating disorder. J Nutr. 2005; 135:1326-30. [PubMed: 15867334]

Geliebter A, Melton PM, McCray RS, Gallagher DR, Gage D, Hashim SA. Gastric capacity, gastric emptying, and test-meal intake in normal and bulimic women. Am J Clin Nutr. 1992; 56:656-61. [PubMed: 1414964]

Germain N, Galusca B, Grouselle D, Frere D, Billard S, Epelbaum J, et al. Ghrelin and obestatin circadian levels differentiate bingeing-purging from restrictive anorexia nervosa. J Clin Endocrinol Metab. 2010; 95:3057-62. [PubMed: 20339027]

Gnanapavan S, Kola B, Bustin SA, Morris DG, McGee P, Fairclough P, et al. The tissue distribution of the mRNA of ghrelin and subtypes of its receptor, GHS-R, in humans. J Clin Endocrinol Metab. 2002; 87:2988. [PubMed: 12050285] 
Goel N, Stunkard AJ, Rogers NL, Van Dongen HP, Allison KC, O’Reardon JP, et al. Circadian rhythm profiles in women with night eating syndrome. J Biol Rhythms. 2009; 24:85-94. [PubMed: 19150931]

Goldstone AP, Holland AJ, Butler JV, Whittington JE. Appetite hormones and the transition to hyperphagia in children with Prader-Willi syndrome. Int J Obes (Lond). 2012

Goto S, Nagao K, Bannai M, Takahashi M, Nakahara K, Kangawa K, et al. Anorexia in rats caused by a valine-deficient diet is not ameliorated by systemic ghrelin treatment. Neuroscience. 2010; 166:333-40. [PubMed: 20006681]

Gourcerol G, Million M, Adelson DW, Wang Y, Wang L, Rivier J, et al. Lack of interaction between peripheral injection of CCK and obestatin in the regulation of gastric satiety signaling in rodents. Peptides. 2006; 27:2811-9. [PubMed: 16934368]

Gourcerol G, Tache Y. Obestatin--a ghrelin-associated peptide that does not hold its promise to suppress food intake and motility. Neurogastroenterol Motil. 2007; 19:161-5. [PubMed: 17300284]

Gualillo O, Lago F, Casanueva FF, Dieguez C. One ancestor, several peptides post-translational modifications of preproghrelin generate several peptides with antithetical effects. Mol Cell Endocrinol. 2006; 256:1-8. [PubMed: 16828223]

Guan HZ, Li QC, Jiang ZY. Ghrelin acts on rat dorsal vagal complex to stimulate feeding via arcuate neuropeptide Y/agouti-related peptide neurons activation. Sheng Li Xue Bao. 2010; 62:357-64. [PubMed: 20717637]

Haqq AM, Farooqi IS, O'Rahilly S, Stadler DD, Rosenfeld RG, Pratt KL, et al. Serum ghrelin levels are inversely correlated with body mass index, age, and insulin concentrations in normal children and are markedly increased in Prader-Willi syndrome. J Clin Endocrinol Metab. 2003; 88:174-8. [PubMed: 12519848]

Helder SG, Collier DA. The genetics of eating disorders. Curr Top Behav Neurosci. 2011; 6:157-75. [PubMed: 21243475]

Holst B, Schwartz TW. Constitutive ghrelin receptor activity as a signaling set-point in appetite regulation. Trends Pharmacol Sci. 2004; 25:113-7. [PubMed: 15058279]

Hosoda H, Kojima M, Matsuo H, Kangawa K. Ghrelin and des-acyl ghrelin: two major forms of rat ghrelin peptide in gastrointestinal tissue. Biochem Biophys Res Commun. 2000; 279:909-13. [PubMed: 11162448]

Hotta M, Ohwada R, Katakami H, Shibasaki T, Hizuka N, Takano K. Plasma levels of intact and degraded ghrelin and their responses to glucose infusion in anorexia nervosa. J Clin Endocrinol Metab. 2004; 89:5707-12. [PubMed: 15531532]

Howard AD, Feighner SD, Cully DF, Arena JP, Liberator PA, Rosenblum CI, et al. A receptor in pituitary and hypothalamus that functions in growth hormone release. Science. 1996; 273:974-7. [PubMed: 8688086]

Hudson JI, Hiripi E, Pope HG Jr, Kessler RC. The prevalence and correlates of eating disorders in the National Comorbidity Survey Replication. Biol Psychiatry. 2007; 61:348-58. [PubMed: 16815322]

Iglesias MJ, Salgado A, Pineiro R, Rodino BK, Otero MF, Grigorian L, et al. Lack of effect of the ghrelin gene-derived peptide obestatin on cardiomyocyte viability and metabolism. J Endocrinol Invest. 2007; 30:470-6. [PubMed: 17646721]

Janas-Kozik M, Krupka-Matuszczyk I, Malinowska-Kolodziej I, Lewin-Kowalik J. Total ghrelin plasma level in patients with the restrictive type of anorexia nervosa. Regul Pept. 2007; 140:43-6. [PubMed: 17187877]

Jerlhag E, Egecioglu E, Dickson SL, Douhan A, Svensson L, Engel JA. Ghrelin administration into tegmental areas stimulates locomotor activity and increases extracellular concentration of dopamine in the nucleus accumbens. Addict Biol. 2007; 12:6-16. [PubMed: 17407492]

Kaye WH, Bailer UF, Frank GK, Wagner A, Henry SE. Brain imaging of serotonin after recovery from anorexia and bulimia nervosa. Physiol Behav. 2005; 86:15-7. [PubMed: 16102788]

Kaye WH, Wagner A, Fudge JL, Paulus M. Neurocircuity of eating disorders. Curr Top Behav Neurosci. 2011; 6:37-57. [PubMed: 21243469] 
Keel PK, Holm-Denoma JM, Crosby RD. Clinical significance and distinctiveness of purging disorder and binge eating disorder. Int J Eat Disord.

Kobelt P, Wisser AS, Stengel A, Goebel M, Bannert N, Gourcerol G, et al. Peripheral obestatin has no effect on feeding behavior and brain Fos expression in rodents. Peptides. 2008; 29:1018-27. [PubMed: 18342400]

Kojima M, Hosoda H, Date Y, Nakazato M, Matsuo H, Kangawa K. Ghrelin is a growth-hormonereleasing acylated peptide from stomach. Nature. 1999; 402:656-60. [PubMed: 10604470]

Kojima M, Kangawa K. Ghrelin: structure and function. Physiol Rev. 2005; 85:495-522. [PubMed: 15788704]

Kojima S, Nakahara T, Nagai N, Muranaga T, Tanaka M, Yasuhara D, et al. Altered ghrelin and peptide YY responses to meals in bulimia nervosa. Clin Endocrinol (Oxf). 2005; 62:74-8. [PubMed: 15638873]

Korbonits M, Gueorguiev M, O'Grady E, Lecoeur C, Swan DC, Mein CA, et al. A variation in the ghrelin gene increases weight and decreases insulin secretion in tall, obese children. J Clin Endocrinol Metab. 2002; 87:4005-8. [PubMed: 12161552]

Korner J, Inabnet W, Febres G, Conwell IM, McMahon DJ, Salas R, et al. Prospective study of gut hormone and metabolic changes after adjustable gastric banding and Roux-en-Y gastric bypass. Int J Obes (Lond). 2009; 33:786-95. [PubMed: 19417773]

Lagaud GJ, Young A, Acena A, Morton MF, Barrett TD, Shankley NP. Obestatin reduces food intake and suppresses body weight gain in rodents. Biochem Biophys Res Commun. 2007; 357:264-9. [PubMed: 17418097]

Leite-Moreira AF, Soares JB. Physiological, pathological and potential therapeutic roles of ghrelin. Drug Discov Today. 2007; 12:276-88. [PubMed: 17395087]

Levin F, Edholm T, Ehrstrom M, Wallin B, Schmidt PT, Kirchgessner AM, et al. Effect of peripherally administered ghrelin on gastric emptying and acid secretion in the rat. Regul Pept. 2005; 131:59-65. [PubMed: 16040140]

Lin E, Gletsu N, Fugate K, McClusky D, Gu LH, Zhu JL, et al. The effects of gastric surgery on systemic ghrelin levels in the morbidly obese. Arch Surg. 2004; 139:780-4. [PubMed: 15249413]

Malik S, McGlone F, Bedrossian D, Dagher A. Ghrelin modulates brain activity in areas that control appetitive behavior. Cell Metab. 2008; 7:400-9. [PubMed: 18460331]

McElroy SL, Frye MA, Hellemann G, Altshuler L, Leverich GS, Suppes T, et al. Prevalence and correlates of eating disorders in 875 patients with bipolar disorder. J Affect Disord. 2010; 128(3): 191-8. [PubMed: 20674033]

Messini CI, Dafopoulos K, Chalvatzas N, Georgoulias P, Anifandis G, Messinis IE. Effect of ghrelin and metoclopramide on prolactin secretion in normal women. J Endocrinol Invest. 2011; 34:2769. [PubMed: 20530986]

Nakazato M, Hashimoto K, Shiina A, Koizumi H, Mitsumoti M, Imai M, et al. No changes in serum ghrelin levels in female patients with bulimia nervosa. Prog Neuropsychopharmacol Biol Psych. 2004; 28:1181-4.

Miljic D, Pekic S, Djurovic M, Doknic M, Milic N, Casanueva FF, Ghatei M, Popovic V. Ghrelin has partial or no effect on appetite, growth hormone, prolactin, and cortisol release in patients with anorexia nervosa. J Clin Endocrinol Metab. 2006; 91:1491-5. [PubMed: 16449333]

Misra M, Miller KK, Kuo K, Griffin K, Stewart V, Hunter E, Herzog DB, Klibanski A. Secretory dynamics of ghrelin in adolescent girls with anorexia nervosa and healthy adolescents. Am J Physiol Endocrinol Metab. 2005; 289:E347-56. [PubMed: 15755766]

Miyasaka K, Hosoya H, Sekime A, Ohta M, Amono H, Matsushita S, et al. Association of ghrelin receptor gene polymorphism with bulimia nervosa in a Japanese population. J Neural Transm. 2006; 113:1279-85. [PubMed: 16362631]

Mondal MS, Toshinai K, Ueno H, Koshinaka K, Nakazato M. Characterization of obestatin in rat and human stomach and plasma, and its lack of acute effect on feeding behavior in rodents. $\mathrm{J}$ Endocrinol. 2008; 198:339-46. [PubMed: 18480381]

Monteleone P, Fabrazzo M, Tortorella A, Martiadis V, Serritella C, Maj M. Circulating ghrelin is decreased in non-obese and obese women with binge eating disorder as well as in obese non-binge 
eating women, but not in patients with bulimia nervosa. Psychoneuroendocrinology. 2005a; 30:243-50. [PubMed: 15511598]

Monteleone P, Martiadis V, Fabrazzo M, Serritella C, Maj M. Ghrelin and leptin responses to food ingestion in bulimia nervosa: implications for binge-eating and compensatory behaviours. Psychol Med. 2003; 33:1387-94. [PubMed: 14672247]

Monteleone P, Martiadis V, Rigamonti AE, Fabrazzo M, Giordani C, Muller EE, et al. Investigation of peptide YY and ghrelin responses to a test meal in bulimia nervosa. Biol Psychiatry. 2005b; 57:926-31. [PubMed: 15820714]

Monteleone P, Serritella C, Martiadis V, Scognamiglio P, Maj M. Plasma obestatin, ghrelin, and ghrelin/obestatin ratio are increased in underweight patients with anorexia nervosa but not in symptomatic patients with bulimia nervosa. J Clin Endocrinol Metab. 2008; 93:4418-21. [PubMed: 18728162]

Monteleone P, Serritella C, Scognamiglio P, Maj M. Enhanced ghrelin secretion in the cephalic phase of food ingestion in women with bulimia nervosa. Psychoneuroendocrinology. 2010; 35:284-8. [PubMed: 19631473]

Monteleone P, Tortorella A, Castaldo E, Di Filippo C, Maj M. The Leu72Met polymorphism of the ghrelin gene is significantly associated with binge eating disorder. Psychiatr Genet. 2007; 17:13-6. [PubMed: 17167339]

Monteleone P, Tortorella A, Castaldo E, Di Filippo C, Maj M. No association of the Arg51Gln and Leu72Met polymorphisms of the ghrelin gene with anorexia nervosa or bulimia nervosa. Neurosci Lett. 2006a; 398:325-7. [PubMed: 16472909]

Monteleone P, Zanardini R, Tortorella A, Gennarelli M, Castaldo E, Canestrelli B, et al. The 196G/A (val66met) polymorphism of the BDNF gene is significantly associated with binge eating behavior in women with bulimia nervosa or binge eating disorder. Neurosci Lett. 2006b; 406:133-7. [PubMed: 16901635]

Morash MG, Gagnon J, Nelson S, Anini Y. Tissue distribution and effects of fasting and obesity on the ghrelin axis in mice. Regul Pep. 2010; 163(1-3):62-73.

Morinigo R, Casamitjana R, Moize V, Lacy AM, Delgado S, Gomis R, et al. Short-term effects of gastric bypass surgery on circulating ghrelin levels. Obes Res. 2004; 12:1108-16. [PubMed: 15292475]

Munsch S, Biedert E, Meyer AH, Herpertz S, Beglinger C. CCK, ghrelin, and PYY responses in individuals with binge eating disorder before and after a cognitive behavioral treatment (CBT). Physiol Behav. 2009; 97:14-20. [PubMed: 19419677]

Tanaka M, Naruo T, Muranaga T, Yasuhara D, Shiiya T, Nakazato M, et al. Increased fasting plasma ghrelin levels in patients with bulimia nervosa. Eur J Endocrinol. 2002; 146:R1-R3. [PubMed: 12039712]

Murphy KG, Bloom SR. Gut hormones and the regulation of energy homeostasis. Nature. 2006; 444:854-9. [PubMed: 17167473]

Nagaya N, Uematsu M, Kojima M, Ikeda Y, Yoshihara F, Shimizu W, et al. Chronic administration of ghrelin improves left ventricular dysfunction and attenuates development of cardiac cachexia in rats with heart failure. Circulation. 2001; 104:1430-5. [PubMed: 11560861]

Nakahara T, Kojima S, Tanaka M, Yasuhara D, Harada T, Sagiyama K, et al. Incomplete restoration of the secretion of ghrelin and PYY compared to insulin after food ingestion following weight gain in anorexia nervosa. J Psychiatr Res. 2007; 41:814-20. [PubMed: 17054989]

Nakai Y, Hosoda H, Nin K, Ooya C, Hayashi H, Akamizu T, et al. Plasma levels of active form of ghrelin during oral glucose tolerance test in patients with anorexia nervosa. Eur J Endocrinol. 2003; 149:R1-3. [PubMed: 12824869]

Nedvidkova J, Krykorkova I, Bartak V, Papezova H, Gold PW, Alesci S, et al. Loss of meal-induced decrease in plasma ghrelin levels in patients with anorexia nervosa. J Clin Endocrinol Metab. 2003; 88:1678-82. [PubMed: 12679456]

Nijhuis J, van Dielen FM, Buurman WA, Greve JW. Ghrelin, leptin and insulin levels after restrictive surgery: a 2-year follow-up study. Obes Surg. 2004; 14:783-7. [PubMed: 15318982]

Nikolopoulos D, Theocharis S, Kouraklis G. Ghrelin, another factor affecting bone metabolism. Med Sci Monit. 2010; 16:RA147-62. [PubMed: 20581789] 
Nishimura H, Komaki G, Ando T, Nakahara T, Oka T, Kawai K, et al. Psychological and weightrelated characteristics of patients with anorexia nervosa-restricting type who later develop bulimia nervosa. Biopsychosoc Med. 2008; 12:2-5.

Nogueiras R, Pfluger P, Tovar S, Arnold M, Mitchell S, Morris A, et al. Effects of obestatin on energy balance and growth hormone secretion in rodents. Endocrinology. 2007; 148:21-6. [PubMed: 17008393]

O’Reardon JP, Peshek A, Allison KC. Night eating syndrome: diagnosis, epidemiology and management. CNS Drugs. 2005; 19:997-1008. [PubMed: 16332142]

Otto B, Cuntz U, Fruehauf E, Wawarta R, Folwaczny C, Riepl RL, et al. Weight gain decreases elevated plasma ghrelin concentrations of patients with anorexia nervosa. Eur J Endocrinol. 2001; 145:669-73. [PubMed: 11720888]

Pardina E, Lopez-Tejero MD, Llamas R, Catalan R, Galard R, Allende H, et al. Ghrelin and apolipoprotein AIV levels show opposite trends to leptin levels during weight loss in morbidly obese patients. Obes Surg. 2009; 19:1414-23. [PubMed: 19172368]

Pemberton CJ, Richards AM. Biochemistry of ghrelin precursor peptides. Vitam Horm. 2008; 77:1330. [PubMed: 17983851]

Prince AC, Brooks SJ, Stahl D, Treasure J. Systematic review and meta-analysis of the baseline concentrations and physiologic responses of gut hormones to food in eating disorders. Am J Clin Nutr. 2009; 89:755-65. [PubMed: 19176730]

Prudom C, Liu J, Patrie J, Gaylinn BD, Foster-Schubert KE, Cummings DE, et al. Comparison of competitive radioimmunoassays and two-site sandwich assays for the measurement and interpretation of plasma ghrelin levels. J Clin Endocrinol Metab. 2010; 95:2351-8. [PubMed: 20194708]

Purtell L, Sze L, Loughnan G, Smith E, Herzog H, Sainsbury A, et al. In adults with Prader-Willi syndrome, elevated ghrelin levels are more consistent with hyperphagia than high PYY and GLP-1 levels. Neuropeptides. 2011; 45:301-7. [PubMed: 21722955]

Qader SS, Håkanson R, Rehfeld JF, Lundquist I, Salehi A. Proghrelin-derived peptides influence the secretion of insulin, glucagon, pancreatic polypeptide and somatostatin: a study on isolated islets from mouse and rat pancreas. Regul Pept. 2008; 146(1-3):230-7. [PubMed: 17942170]

Rosenhagen MC, Uhr M, Schussler P, Steiger A. Elevated plasma ghrelin levels in night-eating syndrome. Am J Psychiatry. 2005; 162:813. [PubMed: 15800168]

Rowe SL, Jordan J, McIntosh VV, Carter FA, Frampton C, Bulik CM, et al. Complex personality disorder in bulimia nervosa. Compr Psychiatry. 2010; 51:592-8. [PubMed: 20965305]

Rowland NE, Morien A, Li BH. The physiology and brain mechanisms of feeding. Nutrition. 1996; 12:626-639. [PubMed: 8878173]

Sakata I, Yang J, Lee CE, Osborne-Lawrence S, Rovinsky SA, Elmquist JK, et al. Colocalization of ghrelin O-acyltransferase and ghrelin in gastric mucosal cells. Am J Physiol Endocrinol Metab. 2009; 297:E134-41. [PubMed: 19401456]

Samson WK, White MM, Price C, Ferguson AV. Obestatin acts in brain to inhibit thirst. Am J Physiol Regul Integr Comp Physiol. 2007; 292:R637-43. [PubMed: 16931650]

Scherag S, Hebebrand J, Hinney A. Eating disorders: the current status of molecular genetic research. Eur Child Adolesc Psychiatry. 2010; 19:211-26. [PubMed: 20033240]

Schindler K, Prager G, Ballaban T, Kretschmer S, Riener R, Buranyi B, et al. Impact of laparoscopic adjustable gastric banding on plasma ghrelin, eating behaviour and body weight. Eur J Clin Invest. 2004; 34:549-54. [PubMed: 15305889]

Schuessler P, Uhr M, Ising M, Schmid D, Weikel J, Steiger A. Nocturnal ghrelin levels--relationship to sleep EEG, the levels of growth hormone, ACTH and cortisol--and gender differences. J Sleep Res. 2005; 14:329-36. [PubMed: 16364133]

Schussler P, Uhr M, Ising M, Weikel JC, Schmid DA, Held K, et al. Nocturnal ghrelin, ACTH, GH and cortisol secretion after sleep deprivation in humans. Psychoneuroendocrinology. 2006; 31:915-23. [PubMed: 16814473]

Shearman LP, Wang SP, Helmling S, Stribling DS, Mazur P, Ge L, et al. Ghrelin neutralization by a ribonucleic acid-SPM ameliorates obesity in diet-induced obese mice. Endocrinology. 2006; 147:1517-26. [PubMed: 16339202] 
Shiiya T, Nakazato M, Mizuta M, Date Y, Mondal MS, Tanaka M, et al. Plasma ghrelin levels in lean and obese humans and the effect of glucose on ghrelin secretion. J Clin Endocrinol Metab. 2002; 87:240-4. [PubMed: 11788653]

Smink FRE, Hoeken D, Hoek HW. Epidemiology of eating disorders: incidence, prevalence and mortality rates. Curr Psychiatry Rep. 2012 [Epub ahead of print].

Soriano-Guillen L, Barrios V, Campos-Barros A, Argente J. Ghrelin levels in obesity and anorexia nervosa: effect of weight reduction or recuperation. J Pediatr. 2004; 144:36-42. [PubMed: 14722516]

Steiger A. Ghrelin and sleep-wake regulation. Am J Physiol Regul Integr Comp Physiol. 2007; 292:R573-4. [PubMed: 16946077]

Sullivan PF. Mortality in anorexia nervosa. Am J Psychiatry. 1995; 152:1073-4. [PubMed: 7793446]

Sun Y, Ahmed S, Smith RG. Deletion of ghrelin impairs neither growth nor appetite. Mol Cell Biol. 2003; 23:7973-81. [PubMed: 14585959]

Sundbom M, Holdstock C, Engstrom BE, Karlsson FA. Early changes in ghrelin following Roux-en-Y gastric bypass: influence of vagal nerve functionality? Obes Surg. 2007; 17:304-10. [PubMed: 17546836]

Suri R, Poist ES, Hager WD, Gross JB. Unrecognized bulimia nervosa: a potential cause of perioperative cardiac dysrhythmias. Can J Anaesth. 1999; 46:1048-52. [PubMed: 10566925]

Tan TM, Vanderpump M, Khoo B, Patterson M, Ghatei MA, Goldstone AP. Somatostatin infusion lowers plasma ghrelin without reducing appetite in adults with Prader-Willi syndrome. J Clin Endocrinol Metab. 2004; 89:4162-5. [PubMed: 15292365]

Tanaka M, Nakahara T, Kojima S, Nakano T, Muranaga T, Nagai N, et al. Effect of nutritional rehabilitation on circulating ghrelin and growth hormone levels in patients with anorexia nervosa. Regul Pept. 2004; 122:163-8. [PubMed: 15491786]

Tanaka M, Naruo T, Yasuhara D, Tatebe Y, Nagai N, Shiiya T, et al. Fasting plasma ghrelin levels in subtypes of anorexia nervosa. Psychoneuroendocrinology. 2003; 28:829-35. [PubMed: 12892652]

Thompson NM, Gill DA, Davies R, Loveridge N, Houston PA, Robinson IC, et al. Ghrelin and desoctanoyl ghrelin promote adipogenesis directly in vivo by a mechanism independent of the type 1a growth hormone secretagogue receptor. Endocrinology. 2004; 145:234-42. [PubMed: 14551228]

Tolle V, Kadem M, Bluet-Pajot MT, Frere D, Foulon C, Bossu C, et al. Balance in ghrelin and leptin plasma levels in anorexia nervosa patients and constitutionally thin women. J Clin Endocrinol Metab. 2003; 88:109-16. [PubMed: 12519838]

Tong J, D'Alessio D. Eating disorders and gastrointestinal peptides. Curr Opin Endocrinol Diabetes Obes. 2011; 18:42-9. [PubMed: 21157325]

Toshinai K, Yamaguchi H, Sun Y, Smith RG, Yamanaka A, Sakurai T, et al. Des-acyl ghrelin induces food intake by a mechanism independent of the growth hormone secretagogue receptor. Endocrinology. 2006; 147:2306-14. [PubMed: 16484324]

Treasure J, Claudino AM, Zucker N. Eating disorders. Lancet. 2010; 375:583-93. [PubMed: 19931176]

Tremblay F, Perreault M, Klaman LD, Tobin JF, Smith E, Gimeno RE. Normal food intake and body weight in mice lacking the G protein-coupled receptor GPR39. Endocrinology. 2007; 148:501-6. [PubMed: 17095592]

Troisi A, Di Lorenzo G, Lega I, Tesauro M, Bertoli A, Leo R, et al. Plasma ghrelin in anorexia, bulimia, and binge-eating disorder: relations with eating patterns and circulating concentrations of cortisol and thyroid hormones. Neuroendocrinology. 2005; 81:259-66. [PubMed: 16131812]

Tschop M, Smiley DL, Heiman ML. Ghrelin induces adiposity in rodents. Nature. 2000; 407:908-13. [PubMed: 11057670]

Tschop M, Weyer C, Tataranni PA, Devanarayan V, Ravussin E, Heiman ML. Circulating ghrelin levels are decreased in human obesity. Diabetes. 2001; 50:707-9. [PubMed: 11289032]

Tsenova L, Harbacheuski R, Sung N, Ellison E, Fallows D, Kaplan G. BCG vaccination confers poor protection against $\mathrm{M}$. tuberculosis HN878-induced central nervous system disease. Vaccine. 2007; 25:5126-32. [PubMed: 17241704] 
van der Lely AJ, Tschop M, Heiman ML, Ghigo E. Biological, physiological, pathophysiological, and pharmacological aspects of ghrelin. Endocr Rev. 2004; 25:426-57. [PubMed: 15180951]

Vendrell J, Broch M, Vilarrasa N, Molina A, Gomez JM, Gutierrez C, et al. Resistin, adiponectin, ghrelin, leptin, and proinflammatory cytokines: relationships in obesity. Obes Res. 2004; 12:96271. [PubMed: 15229336]

Vink T, Hinney A, van Elburg AA, van Goozen SH, Sandkuijl LA, Sinke RJ, et al. Association between an agouti-related protein gene polymorphism and anorexia nervosa. Molecular psychiatry. 2001; 6:325-8. [PubMed: 11326303]

Weltzin TE, Fernstrom MH, Hansen D, McConaha C, Kaye WH. Abnormal caloric requirements for weight maintenance in patients with anorexia and bulimia nervosa. Am J Psychiatry. 1991; 148:1675-82. [PubMed: 1957930]

Whitson BA, Leslie DB, Kellogg TA, Maddaus MA, Buchwald H, Billington CJ, et al. Enteroendocrine changes after gastric bypass in diabetic and nondiabetic patients: a preliminary study. J Surg Res. 2007; 141:31-9. [PubMed: 17574036]

Woldt L, Schneider N, Pfeiffer E, Lehmkuhl U, Salbach-Andrae H. Psychiatric disorders among parents of patients with anorexia nervosa and bulimia nervosa. Prax Kinderpsychol Kinderpsychiatr. 2010; 59:302-13. [PubMed: 20491429]

Wortley KE, del Rincon JP, Murray JD, Garcia K, Iida K, Thorner MO, et al. Absence of ghrelin protects against early-onset obesity. J Clin Invest. 2005; 115:3573-8. [PubMed: 16322795]

Wren AM, Seal LJ, Cohen MA, Brynes AE, Frost GS, Murphy KG, et al. Ghrelin enhances appetite and increases food intake in humans. J Clin Endocrinol Metab. 2001; 86:5992. [PubMed: 11739476]

Yamamoto D, Ikeshita N, Daito R, Herningtyas EH, Toda K, Takahashi K, et al. Neither intravenous nor intracerebroventricular administration of obestatin affects the secretion of GH, PRL, TSH and ACTH in rats. Regul Pept. 2007; 138:141-4. [PubMed: 17055593]

Yang J, Brown MS, Liang G, Grishin NV, Goldstein JL. Identification of the acyltransferase that octanoylates ghrelin, an appetite-stimulating peptide hormone. Cell. 2008; 132:387-96. [PubMed: 18267071]

Yanovski SZ, Nelson JE, Dubbert BK, Spitzer RL. Association of binge eating disorder and psychiatric comorbidity in obese subjects. Am J Psych. 1993; 150(10):1472-9.

Yasuhara D, Naruo T, Nagai N, Tanaka M, Muranaga T, Nozoe S. Insulinogetic index at 15 min as a marker of nutritional rehabilitation in anorexia nervosa. Am J of Clin Nutr. 2003; 77:292-9. [PubMed: 12540385]

Zhang JV, Ren PG, Avsian-Kretchmer O, Luo CW, Rauch R, Klein C, et al. Obestatin, a peptide encoded by the ghrelin gene, opposes ghrelin's effects on food intake. Science. 2005; 310:996-9. [PubMed: 16284174]

Zigman JM, Nakano Y, Coppari R, Balthasar N, Marcus JN, Lee CE, et al. Mice lacking ghrelin receptors resist the development of diet-induced obesity. J Clin Invest. 2005; 115:3564-72. [PubMed: 16322794]

Zwirska-Korczala K, Konturek SJ, Sodowski M, Wylezol M, Kuka D, Sowa P, et al. Basal and postprandial plasma levels of PYY, ghrelin, cholecystokinin, gastrin and insulin in women with moderate and morbid obesity and metabolic syndrome. J Physiol Pharmacol. 2007; 58 (Suppl 1): 13-35. [PubMed: 17443025] 


\section{Highlights}

1. Ghrelin in eating disorders has been the topic of recent investigations.

2. There are inconsistent reports on ghrelin levels in eating disorder patients.

3. Different forms of ghrelin used may explain these inconsistencies.

4. Body weight may be an important factor on determining ghrelin levels in eating disorders. 


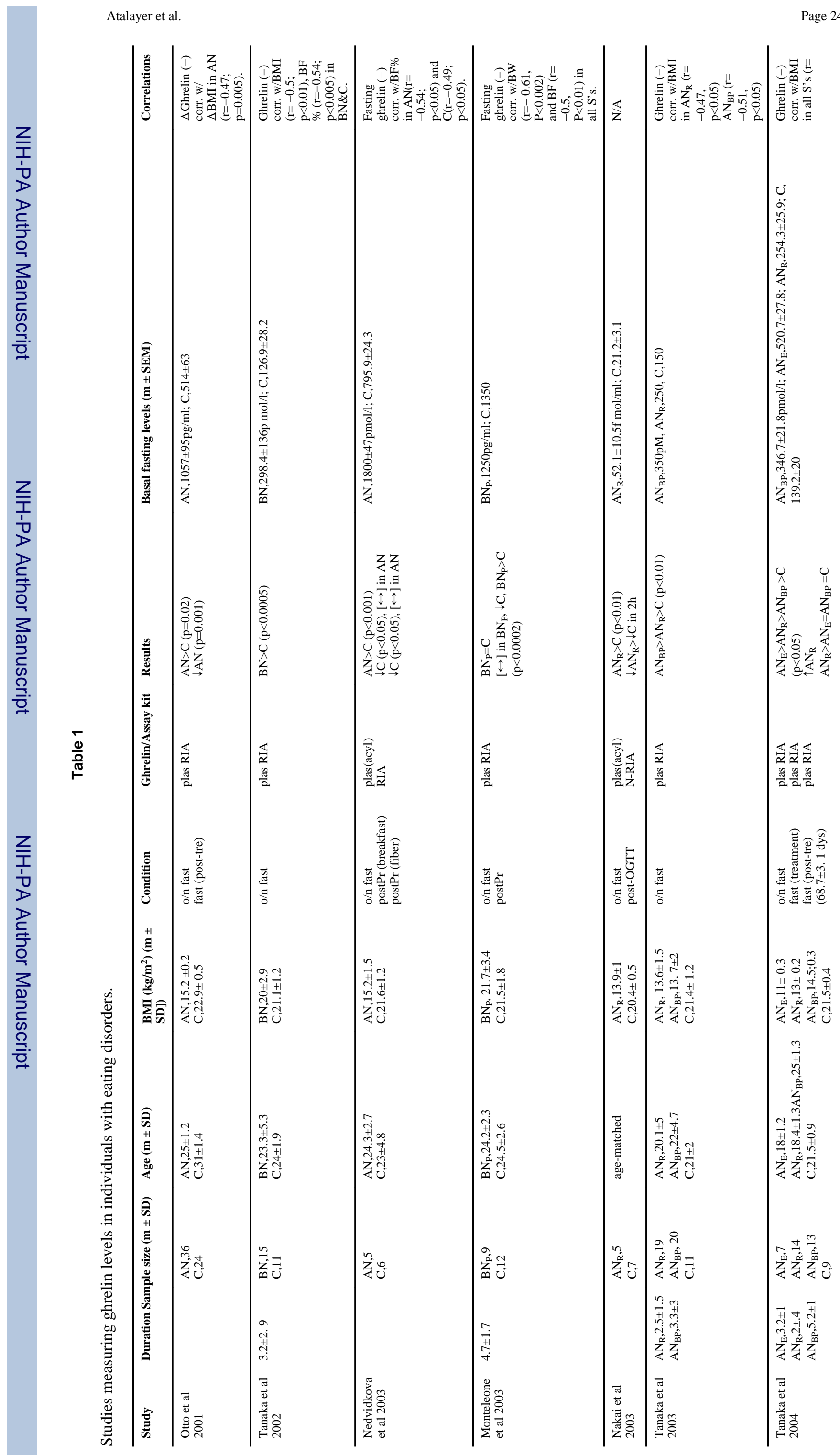




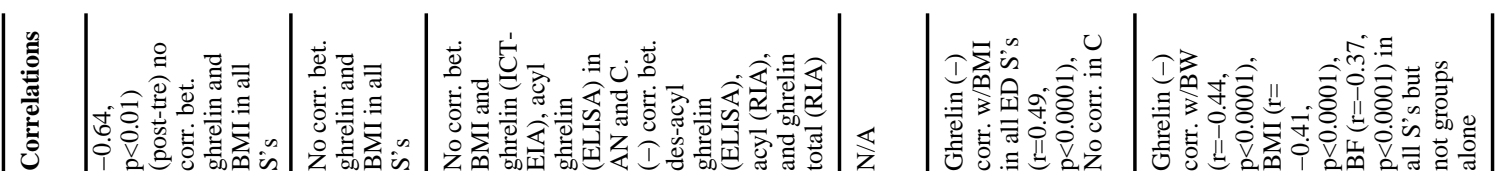

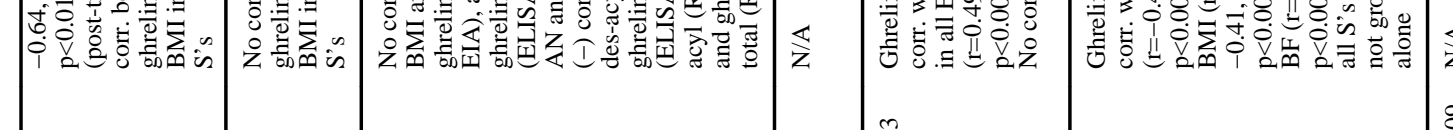

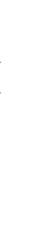

然学军

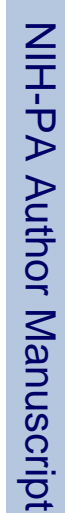

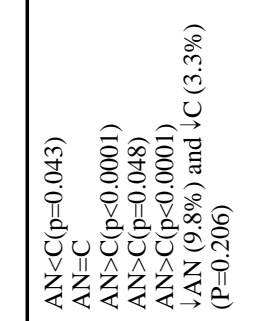

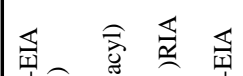

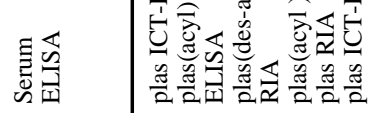

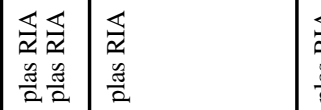

줄

$\frac{0}{2} \frac{0}{2}$
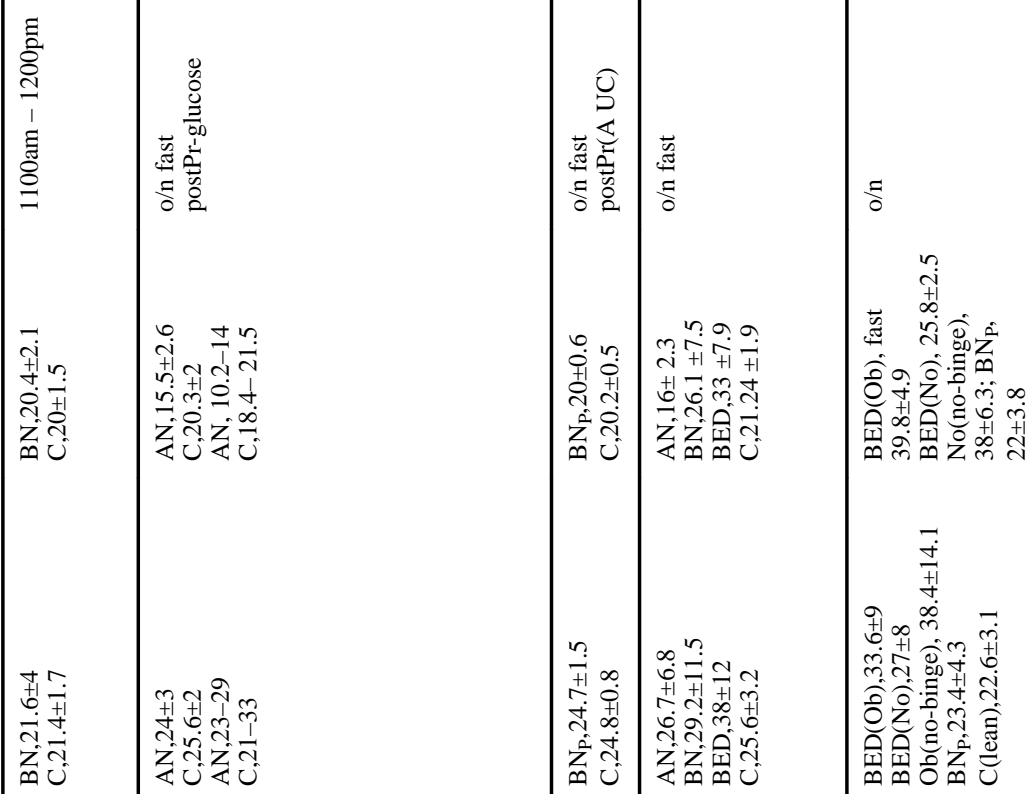


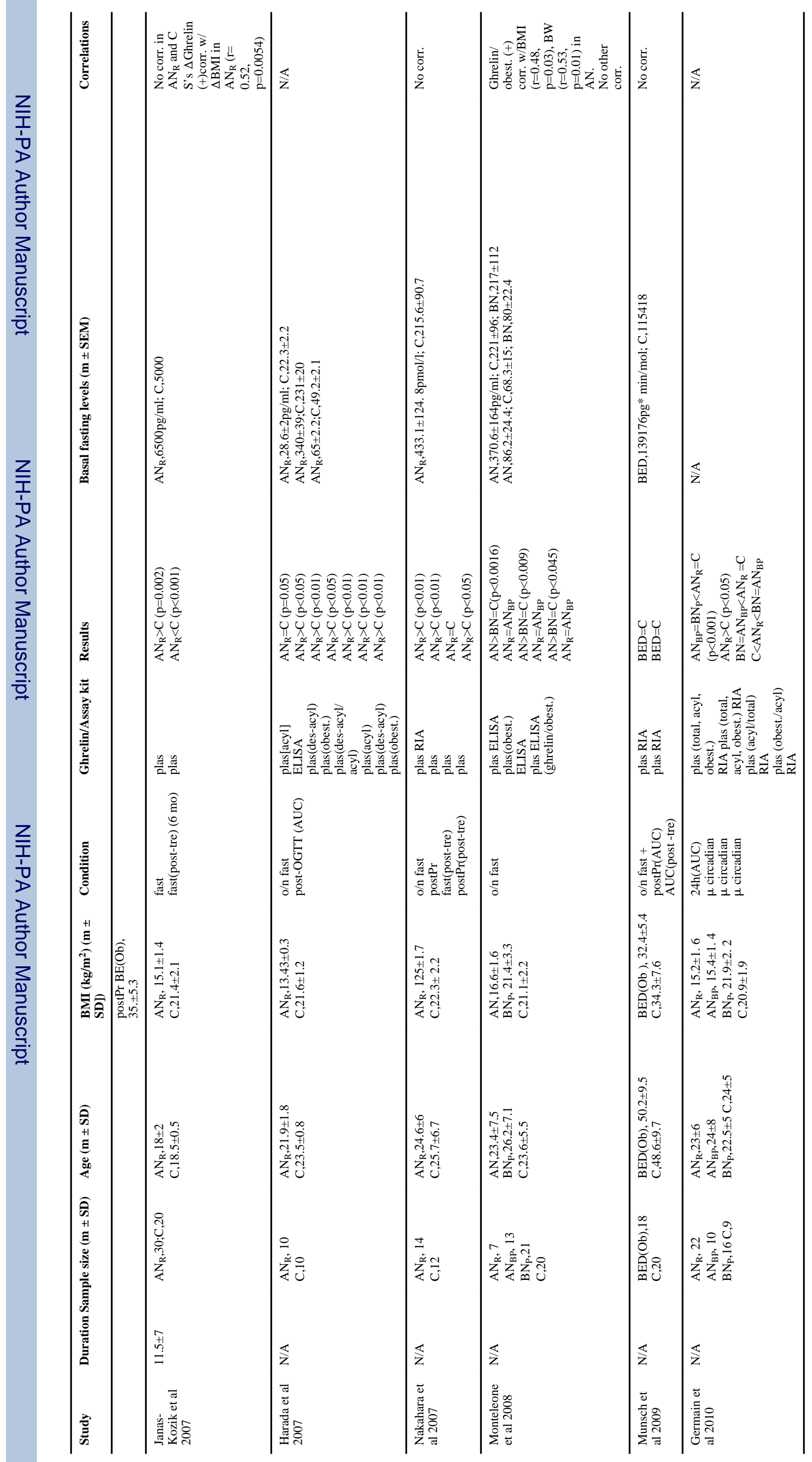





\section{Table 2}

Summary of the results from the studies in Table 1.

\begin{tabular}{ll}
\hline Variable & \# of studies \\
\hline Correlation bet. ghrelin and BMI \\
{$[-]$ corr. } & 6 \\
{$[+]$ corr. } & 3 \\
No corr. & 7 \\
\hline Correlation bet. ghrelin and BF \\
[-] corr. & 4 \\
[+] corr. & 0 \\
No corr. & 1 \\
\hline Ghrelin levels AN vs. C \\
AN $>C$ & 11 \\
AN=C & 3 \\
AN $<C$ & 2 \\
\hline Ghrelin levels BN vs. C \\
BN $>C$ & 2 \\
BN=C & 6 \\
BN $<C$ & 1 \\
\hline Ghrelin levels BED vs. C \\
BED $>C$ & 0 \\
BED=C & 2 \\
BED $<C$ & 2 \\
\hline
\end{tabular}


Table 3

Abbreviations used in Tables 1 and 2.

\begin{tabular}{|c|c|}
\hline Abbreviation & Definition \\
\hline Acyl/total & Acyl ghrelin/total ghrelin ratio \\
\hline AN & Anorexia Nervosa (all types) \\
\hline $\mathbf{A \mathbf { N } _ { \mathbf { E } }}$ & Anorexia Nervosa, requiring Emergent Hospitalization \\
\hline $\mathbf{A N}_{\mathrm{BP}}$ & Anorexia Nervosa, Binge-eating/Purge subtype \\
\hline $\mathbf{A} \mathbf{N}_{\mathbf{R}}$ & Anorexia Nervosa, Restricting subtype \\
\hline AUC & Area Under the Curve \\
\hline $\mathbf{B E}$ & Binge Eater (not full BED criteria) \\
\hline BED & Binge Eating Disorder \\
\hline bet. & between \\
\hline BN & Bulimia Nervosa (all types) \\
\hline $\mathbf{B N}_{\mathbf{P}}$ & Bulimia Nervosa, Purging subtype \\
\hline $\mathbf{B N}_{\mathrm{NP}}$ & Bulimia Nervosa, Non-Purging subtype \\
\hline BMI & Body Mass Index \\
\hline BW & Body weight \\
\hline BF & Body Fat \\
\hline $\mathbf{C}$ & Control group \\
\hline corr. & Correlation \\
\hline dys & Days \\
\hline ELISA & Enzyme-Linked Immunosorbent Assay \\
\hline Ghrelin/obest. & Ghrelin/Obestatin Ratio \\
\hline $\mathbf{H}$ & Hours \\
\hline mo & Months \\
\hline N/A & Not Applicable \\
\hline No & Non-obese \\
\hline NW & Normal Weight \\
\hline Ob & Obese \\
\hline obest. & Obestatin \\
\hline OGTT & Oral Glucose Tolerance Test \\
\hline Obest./acyl & Obestatin/Acyl ghrelin ratio \\
\hline $\mathbf{o} / \mathbf{n}$ fast & Overnight Fast \\
\hline obest./acyl & Obestatin/Acyl ghrelin ratio \\
\hline plas & Plasma \\
\hline PostPr & Postprandial \\
\hline Post-tre & Post-treatment \\
\hline RIA & Radioimmuno Assay \\
\hline SEM & Standard Error of the Mean \\
\hline S's & Subjects \\
\hline w/ & With \\
\hline yrs & Years \\
\hline
\end{tabular}




\begin{tabular}{ll}
\hline Abbreviation & Definition \\
\hline$\Delta$ Ghrelin & Change in Ghrelin \\
{$[-]$ corr. } & Negative correlation \\
{$[+]$ corr. } & Positive correlation \\
{$[\leftrightarrow]$} & No change \\
$\downarrow$ & Decrease \\
$\uparrow$ & Increase \\
$\&$ & Combined \\
$\mu$ & Mean \\
\hline
\end{tabular}

